\title{
Background
} Paper

\section{YOUTH CULTURES:} VALUES, REPRESENTATIONS AND SOCIAL CONDITIONS Ilenya Camozzi,
Daniela Cherubini,
Carmen Leccardi,
Paola Rivetti,
University of Milan-Bicocca

In collaboration with: Carles Feixa Pàmpols, Jose Sánchez García,

University of Lleida

Annex I edited by Driss Ksikes,

Fadma Aït Mous, Institut des Hautes Etudes de Management

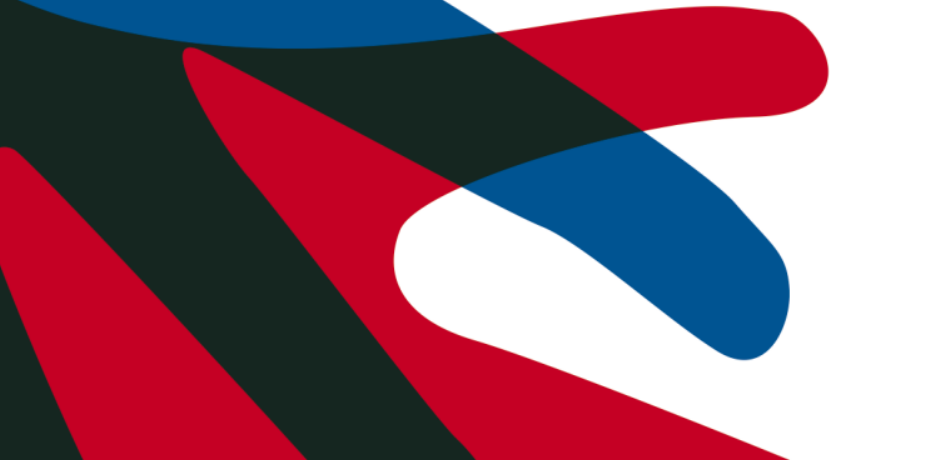


Youth Cultures: Values, Representations and Social Conditions 


\begin{abstract}
The paper provides the conceptual and analytical background for the thematic Working Package number 4 "Youth cultures: values, representations and social conditions". It shows the relevance of the cultural dimension in the study of youth condition, in order to understand young people's actions and to recognise youth agency. Nowadays, the transition to adulthood takes place in the context of growing uncertainty and deep social, cultural and political transformations also in contemporary Arab Mediterranean societies.

The first part of the paper defines the conceptual framework for the study of youth agency and cultures. After reconstructing the development of the reflexion on youth and youth cultures by sociology and social science from the 1920 s to the 2000 s, it focuses on the main topics, trends and gaps of contemporary studies on youth cultures in Western contexts and in Arab Mediterranean countries. The second part of the paper outlines the research questions and analytical dimension that will guide the research in WP4. The main questions can be summarised as follows:

How the cultural construction of youth is changing in Arab Mediterranean countries? To what extent does youth appear as a condition marked by specific cultural expressions and subjectivities, rather than a mere transitional stage of life? How do the changes in the transition to adulthood impact on the emergence of new cultural trends among Arab youths? Which are the strategies that young men and women deploy for constructing their identity, shaping their biographical projects and giving meaning to their social world, in the changing contexts of Arab Mediterranean countries?
\end{abstract}

Keywords: Youth cultures - Youth agency - Youth identity and subjectivities - Gender models Social values - Social representations. 
SAHWA Background Paper 03-2015

Ilenya Camozzi, Daniela Cherubini, Carmen Leccardi, Paola Rivetti with Carles Feixa and Jose Sánchez 


\section{SUMMARY}

1. Introduction and justification of the relevance of the issue for the project .................................... 3

PART 1 - LITERATURE REVIEW AND CONCEPTUAL FRAMEWORK................................... 6

2. The development of the conceptual framework for the study of youth and youth cultural practices . 6

2.1 The Chicago school: the cultural practices of juvenile deviant groups ............................. 6

2.2. Karl Mannheim and the concept of generation ......................................................... 7

2.3 Erikson's contribution to the issue of youth identity ..................................................... 9

2.4 The structural-functionalist paradigm and the discovery of "youth culture" ................... 10

2.5 Critical sociology on youth movement and counter-culture ….................................. 12

2.6 The Centre for Contemporary Cultural Studies in Birmingham and the concept of

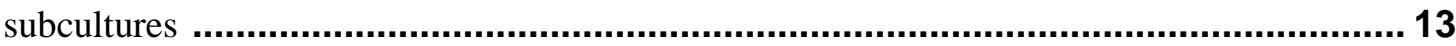

2.7 Critics of the Birmingham school and the "post-subcultural" turn ................................ 15

3. Contemporary studies on youth and youth cultures in European and Western contexts ................. 22

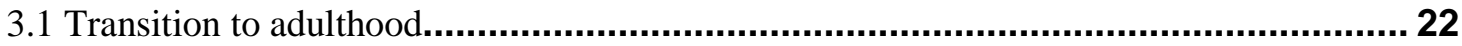

3.2 Main trends and gaps in contemporary studies on youth cultures ................................... 24

3.2.1 Leisure time, new technologies and media, and practices of consumption............... 25

3.2.2 Political participation, engagement and citizenship .............................................. 29

3.2.3 Identity and values in the local/global context .................................................... 31

4. Contemporary studies on youth and youth cultures in the South Mediterranean and Middle East

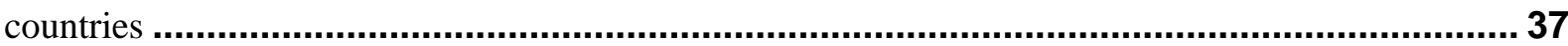

4.1 The contribution of youth cultures to the study of youth in Arab Mediterranean countries37

4.2 The scholarship on youth in Arab Mediterranean countries ........................................ 38

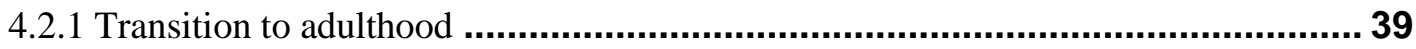

4.2.2 Main trends and gaps in contemporary studies on youth cultures .......................... 39

4.2.3 Youth and internal differences.............................................................................. 41

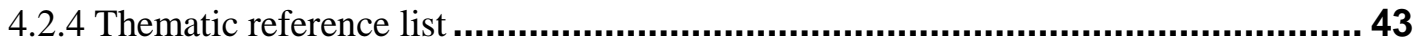

PART 2: RESEARCHING YOUTH CULTURES IN THE SAHWA PROJECT ...............................51

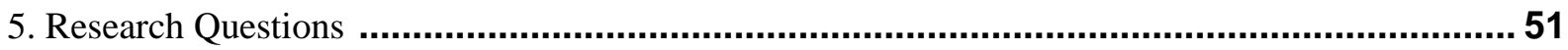


SAHWA Background Paper 03-2015

Ilenya Camozzi, Daniela Cherubini, Carmen Leccardi, Paola Rivetti with Carles Feixa and Jose Sánchez 


\section{Introduction and justification of the relevance of the issue for the project}

This paper provides the conceptual and analytical background for the thematic Working Package number 4, on "Youth cultures: values, representations and social conditions", within the FP7 Research Project "Empowering the Young Generation: Towards a New Social Contract in South and East Mediterranean Countries (SAHWA)".

As described in the DOW, SAHWA aims to explore the contemporary dynamics and changes in youth condition in the Arab Mediterranean countries, from a comparative and critical perspective. The thematic WP4 aims to identify, describe and analyse the different norms, social values and cultural practices of young people of the Arab Mediterranean countries involved in the research project (Algeria, Egypt, Lebanon, Morocco and Tunisia), in order to understand the role of young people, as cultural agents, in the process of sociocultural and political change, democratic transition and youth empowerment in these contexts.

In this framework, the core idea behind the paper is the relevance of culture and cultural dimensions in the study of youth. The analysis of the structural and economic factors that shape the lives of young people is not sufficient in order to build a full understanding of the characters and tendencies of youth conditions in Arab Mediterranean countries (as in every sociocultural and geographical context). As Furlong and colleagues note: "To ignore or sideline youth culture results in a one-dimensional picture of young lives in which the active way that young people negotiate constraints and opportunities is portrayed as marginal to the process of social reproduction. It is through the study of youth culture that we build an awareness of the ways young people interpret, construct and shape their lives within a given set of circumstances" (Furlong, Woodman and Wyn, 2011: 357). Therefore, in order to achieve the scientific objectives of the project, it is important to include a specific attention on youth values, norms, cultural orientations and practices in the SAHWA analytical framework.

Yet the scholarship on youth proceeded in two parallel approaches, since its beginnings ${ }^{1}$ : a structural approach that focuses on the transition from the young age to adulthood, and a cultural approach that is interested in youth cultures and youth cultural practices. The present paper focuses on the core questions and a conceptual tool elaborated within this second strand of analysis, and connects them to the broader SAHWA perspective, which is built around the idea of the integration between the two approaches and aims to integrate the account of both the cultural and structural aspects that marks youth conditions in contemporary societies. The SAHWA project encompasses a special focus on the cultural and symbolic work of young people, in their effort to give meaning to and handle the constraints and resources linked to their structural position.

As will be explained in detail in the paper, the interest for youth and youth cultural practice by both social sciences and in public debate can reflect two different approaches: the first one conceives youth as a potential danger to social order, the second looks at young people as social actors who are potentially involved in processes of social and cultural innovation. In

\footnotetext{
${ }^{1}$ It is well-known that 'youth' as a specific stage of the human biography has been singled out and defined in the late 19th century. Thus the 'modern invention of youth' (Gillis 1974) inaugurated a new field of study later than other fields of study in sociology. See Ariès 1960; Galland 1997; Mitterauer, 1986, for a sociological account of the history of youth.
} 
other words, the attention paid to the cultural practices of young people can proceed from two opposite premises: it can respond to a concern for juvenile deviance and the problem of social order, or to an interest in the processes of social change and innovation. The SAHWA Project embraces the second approach, and relies on the recognition of social, political and cultural agency of young people. It conceives young people as active agents who contribute to the production, reproduction and innovation of cultural values, norms, orientations and meanings of the society in which they live. Therefore, it manifests a specific interest in the practices of cultural consumption and production enacted by young people, for the forms of identity construction and the processes of subjectification that involve young men and women.

Youth became a social category, relevant for public discourse and social sciences, when it began to be recognised as the result of specific and located processes of cultural construction, rather than simply a matter of age, related to the demographic succession of life stages. This means that both its boundaries and contents (values, expectations, roles and prescriptions related to young people, in contrast or in comparison to those associated with other life stages, and in particular to adult life) are culturally defined and are strictly connected to the dynamics of social change. More in detail, youth emerged as an object for sociological analysis since it acquired certain autonomy in the cultural field, and came to be associated with a differential identity, social location and cultural expression: in a word, with the emergence of specific youth cultures.

Defined as such, youth and specifically the issue of the cultural practices and identities that shape youth conditions are central for understanding the current processes of social and political transition in contemporary Arab Mediterranean societies.

The first set of reasons revolves around the issue of political Islam and popular mobilisation the Arab Mediterranean region. Traditionally, the field of Middle Eastern Studies has advanced the hypothesis that political Islam is a driving social and political force in the Arab Mediterranean countries to the point of "wrapping up" all of the possible outcomes of and reasons for protests (Roy 2008, Austin 2011). Despite this perspective being dominant, political Islam has played a very marginal role in the uprisings, although it was very successful at elections. This "unstable" dynamic revolving around the issue of religion and politics does not only suggest that political Islam is a contested concept, but also that it is time to dismantle assumptions about change in the Middle East. Indeed, the Arab Mediterranean countries have long been caught between contradictory totalising visions: authoritarian regimes constituting a progressive step in an evolution towards democracy - perceived as an exclusively "Western" notion - or countries doomed to succumb to radical Islamism. It is very important to dismantle this dichotomous representation by looking closely at values and changing youth cultures, with the goal of enriching our understanding of the cultural dynamic identity produced by the Arab Mediterranean youth.

The second set of reasons why it is important to engage youth culture in the Arab Mediterranean countries is that young people taking the streets during the uprisings were not those that scholars expected to be. Indeed, the scholarship on youth political engagement and participation has mainly focused on the so-called "usual suspects" (Aarts and Cavatorta 2013), namely young people participating into secular or religious NGOs and charities, usually with a middle-class background. The uprisings highlighted the presence and political engagement of socially marginal constituencies (Beinin 2014), in particular young people 
coming from poor neighbourhoods (Merone 2015). This speaks to the necessity of bringing those seemingly "non-political" social movements (football fan clubs, for instance) into the broader picture of youth political participation, in order to examine and getting familiar with the culture and values they express. Therefore, it is important to understand not only "who" these young people are, but also "what kind of values and culture" they express.

In order to explore these issues, the paper is structured as follows: The first part of the paper defines the conceptual framework for the study of youth condition and the analysis of youth subjectivities and cultures. Chapter 2 reconstructs the development of the sociological reflexion on youth, since the 1920s, mostly in Western contexts. It shows the development of a special focus on young people as producers and consumers of culture within sociological thinking (often in relation with other social sciences), and how different perspectives have taken account of the cultural agency of young people. The following chapters present the main trends and topics, and provide a glance at the most relevant gaps, of contemporary youth studies and literature on youth cultures at the international level (Chapter 3) and in the Arab Mediterranean countries involved in the SAHWA project (Chapter 4). The second part of the paper explores the directions of application of this conceptual framework in the SAHWA project. Chapter 5 articulates the research questions for the Working package 4 "Youth cultures: values, representations and social conditions".

\section{References to Chapter 1}

Ariès, P. (1960) L'Enfant et la vie familiale sous l'Ancien Régime. Paris, Plon.

Aarts, P., Cavatorta, F., eds., (2013) Introduction. In Rienner, L., Civil Society in Syria and Iran: Activism in Authoritarian Contexts, pp. 1-17.

Anceschi, L., Gervasio, G., Teti, A., eds. (2014), Informal Power in the Greater Middle East: Hidden Geographies. Routledge.

Beinin, J. (2014) Civil Society, NGOs, and Egypt's 2011 Popular Uprising. South Atlantic Quarterly, 133 (2), pp. 396-403.

Furlong, A., Woodman, D. and J. Wyn (2011) Changing times, changing perspectives: Reconciling "transition" and "cultural" perspectives on youth and young adulthood. Journal of Sociology, 47(4): pp. 355-370.

Galland, O. (1997) Sociologie de la jeunesse. Paris: Armand Colin.

Gillis, J. (1974) Youth and History: Tradition and Change in European Age Relations, 1170Present. New York: Academic Press. 
Merone, F. (2015), Enduring Class Struggle in Tunisia: The Fight for Identity beyond Political Islam. British Journal of Middle Eastern Studies, 42(1): pp. 74-87.

Mitterauer M. (1986) Sozialgeschichte der Jugend. Frankfurt am Main, Suhrkamp. 


\title{
PART 1. LITERATURE REVIEW AND CONCEPTUAL FRAMEWORK
}

\author{
2. The development of the conceptual framework for the study of youth and youth \\ cultural practices
}

This section reconstructs the development of the reflexion on youth and youth cultures by sociology and social science from the 1920 s to the 2000 s, mostly in western contexts. It analyses the transformation of the ways of conceptualizing youth and youth cultures, from the first definition of the field by the Chicago school, to the analysis of youth subcultures produced at the Centre for contemporary cultural studies in Birmingham, and to the postsubcultural approaches. Each section focus on key moments of this field of studies, providing a glimpse into their main questions, conceptual tools, as well limitations, bias and critical points.

\subsection{The Chicago school: the cultural practices of juvenile deviant groups}

The first corpus of studies on youth cultural practices and behaviours can be traced back to the 1920s, when scholars from the Department of Anthropology and Sociology at Chicago University carried out several empirical research projects on deviant and delinquent urban youth groups.

This research, involved in what is known as the "Chicago school", engaged the ethnographic study of urban populations and territories with an ecological approach (Parks et al. 1925), focusing on the spatial dimensions of the socio-cultural transformations of the city of Chicago. These studies should be understood in relation to the context in which they were developed: a metropolitan context affected by high immigration rates, rapid demographic growth and by deep urban transformations. Within this frame, the driving force was a concern for the issue of social disorganisation and for the negative consequences of rapid social change. Young people, and in particular the groups of (mostly male) youngsters of recent immigrant origins, or who belonged to the marginal sectors of the urban population, were among the most visible and emblematic manifestations of these phenomena, who aroused great public attention. They became the privileged object of this strand of research, that focused on specific juvenile groups which shared a common position of deviance and marginality (e.g. delinquent youth, youth gangs from suburban areas and slums), rather than on "youth" as a general social category.

Seminal works on this subject were, for instance, research on "hobos" by Nels Anderson (1923), the study of the female juvenile culture known as "flappers" by William Isac Thomas (1923), the huge and comprehensive investigation on Chicago's youth gangs by Fredreric Thrasher (1927), research concerning the dancers of the city's dance halls, developed by Paul Cressey (1932), the life-story based study on juvenile delinquency by Clifford Shaw (1930) and the ethnographic analyses of peer relations and social organisation among second generation young Italian men in the slum area of Little Italy by William Foote Whyte (1955). Most of these studies focused on the cultural practices of male youth, with the notable exceptions of the mentioned works of Thomas (1923) and Cressey (1932). 
What emerged from these empirical works was that these juvenile groups shared values and styles of behaviour that differed from those of the mainstream and adult society. Here the idea of youth culture emerged for the first time, as a set of practices, behaviours, values and cultural orientations that are distinct and clearly distinguishable from the mainstream ones. Therefore, in this first formulation youth culture was conceived as deviant culture. It was seen as the cultural expression of marginality and of the lack of social cohesion, strongly connoted in terms of age (the culture of juvenile groups) and socio-spatial location (the cultures of the slums, the ghettos, the underclass urban areas). As such, the affiliation to a group of peers expressing a deviant behaviour was believed to have an impact on the moral career of its members and even to be able to set one on a course of criminality.

Yet the concept of deviance that lies at the core of the Chicago school's research is worth analysing in more depth. A key feature of this approach is the attention paid to social and spatial dimensions of deviance and deviant behaviour, which therefore is understood in relation to their structural and ecological roots, rather than reduced to mere individual dispositions or classified as an individual pathology.

Part of the key features of the Chicago school's reflections on deviance were further integrated and re-elaborated under the structural-functionalism paradigm by Robert Merton (1938). As such, the analysis of youth deviant behaviours and cultures continued also into further decades, especially with studies on youth gangs and youth delinquency, beyond the clear boundaries of the Department of Anthropology and Sociology at Chicago University. For instance, the work "Delinquent Boys" by Albert Cohen (1955) is a reference study along this line of research. It advanced for the first time the idea that youth cultures could be interpreted as (deviant) responses to social contradictions; in particular, those contradictions experienced by working-class youth in a society ruled by the middle-class and its culture. In this sense, Cohen's analysis anticipated some of the key features of the framework developed by scholars based at the Centre for Contemporary Cultural Studies of the University of Birmingham, in the 1970s (see paragraph 2.6).

\subsection{Karl Mannheim and the concept of generation}

The second and fundamental stage in studies on youth is the sociological theory of generation elaborated by Karl Mannheim (1927). In his essay "The Sociological Problem of Generation" (1927), the author elaborated a refined theoretical revision of the concept of generation, which had previously been formulated under the positivist paradigm (Comte 1830-1842) as well as in Dilthey's Historicism (Dilthey 1883) ${ }^{2}$. In Mannheim's view, the problem of generations is a key question for sociology because it is strongly linked to the issue of social change. The formation and succession of generations is one of the driving forces that marks the patterns and pace of social change; however, it does not follow a mechanical and predictable chronological order. In order to give account to this complex connection between generations and social change, Mannheim distinguished three analytical concepts: the "generation

\footnotetext{
2 Mannheim criticised the positivist view, which considers the succession of generations as largely dependent on biological factors and therefore measurable in quantitative terms. At the same time, he also departed from the approach of historicism, which in his view underestimated the role of social factors in fostering the emergence of a generation and in shaping the sequence between generations.
} 
location", the "actual generation" (based on a "generational bond") and the "generational unit".

The first term (generation location) refers to a common location in the historical and social dimension: it includes people belonging to the same age group within a given society, who potentially can be exposed at the same time to the same historical and social circumstances, or are in the position to share common experiences. When it happens, i.e. when people experience the same historical events at the same age - and especially in their youth - a generational bond can emerge: a common orientation and worldview, a consciousness, a feeling of belonging to an actual generation. In other words, the generation location is just a precondition for the formation of a generation as an actuality. The third and last term (generational units) refers to "groups within the same actual generation which work up the material of their common experiences in different specific ways" (Mannheim 1927: 184). They "do not merely involve a loose participation by a number of individuals in a pattern of events shared by all alike though interpreted by the different individuals differently, but an identity of responses, a certain affinity in the way in which all move with and are formed by their common experiences" (Mannheim 1927: 185-186). Different generational units can arise within the same actual generation, among people who share a common destiny.

Following the author's elaboration, being born at similar periods in history, living in the same period or merely sharing contemporaneity are not enough to belong to the same generation. It is necessary to share a common set of experiences and to take part together to the flux of historical events, especially in the case that these events entail a rapid social change and disrupt the continuity of and have a profound impact on both collective and individual time. Moreover, the emergence of a generational bond and unit will be much more likely when these events are experienced during youth, because this is the time of socialisation and the first entry in the public life, when individuals begin to become aware of their social locations and of the connections between their individual lives and historical time. In this stage of life the experiences of historical and social circumstances lead to "early impressions which tend to coalesce into a natural view of the world" (Mannheim 1927: 177) and function as key factors in the "stratification of experience", as reference points for the interpretation of all the next life experiences.

Here emerges an important point in the author's theory, which was elaborated further in later works (see for instance Mannheim 1936): the connection between youth, social change and innovation. Young people do not take social order for granted, they have not yet internalised all the habits, norms and traditional worldview as have adults: from a sociological point of view, they can be seen as outsiders. For this reason, youth has a potential for social and cultural innovation, a potential that can be either exploited, or controlled and repressed, by different societies and in different historical moments.

This reflection on the sociological function of youth can be seen as one of the fundamental theoretical contributions that Mannheim's perspective provides to the study of youth, beside the concept of generation.

Another fundamental insight relates to the issue of pluralism and difference within the youth. The concept of generational units takes into account the fact that young people who share the same generational locations can actually be affected by their common experiences in different 
ways, developing different cultural orientations and worldviews. Mannheim's theory of generation gives room to the idea of the coexistence of more than one generation unit, and it can be extended to encompass the existence of plural and heterogeneous youth cultures within the same society and historical time.

The concept of generation has been very influential in youth studies and in sociology of youth (Leccardi and Feixa 2010). It has been incorporated in different analytical frameworks during the second half of the twentieth century, as we will explain in the following paragraphs. It has also been incorporated into the everyday and media languages and in popular conceptions on youth.

On the one hand, sometimes it has been used in a broad way to describe a juvenile way of life or to identify a category of people ideally bonded together by common social, cultural or political circumstances, without making use of Mannheim's fine distinction between "generational location", "bond" and "unit". On the other hand, and more notably, Mannheim's theory has been the object of refined sociological revisions. Among them the analysis by Philip Abrams (1982) with its focus on identity and the linkage between biographical and social-historical time, and the conceptualisation by Carmen Leccardi (Leccardi 1996, 2000, 2002) with its emphasis on the dimension of reflexivity and the connection to the concept of genealogy, are worth mentioning ${ }^{3}$.

\subsection{Erikson's contribution to the issue of youth identity}

The widespread dynamics of modernisation and social transformation which characterised western societies in the second post-war period had a profound impact on the reconfiguration of youth and its location within the wider society. The growth of educational rate, changes in values and in the traditional mechanism of youth socialisation, and the emergence of the cultural industry specifically dedicated to youth consumption and leisure all figure among the elements that contributed to mark this transformation of youth. Besides that, there was the new phenomenon of youth movements in the 1950s and 1960s.

This evolution captured the attention of social science, which developed a strong interest for the social category of youth. It was within this framework and period that the term "youth culture" was introduced to the social sciences, although from this bibliographical review it is clear that issues related to young people's styles of behaviour, values and cultural practices were already objects of sociological attention in the previous decades. This was the first time that young people, all young people as a social category, were recognised (and begin to see themselves) as bearers of a distinct and separate culture, as part of a cultural world which is partly independent from that of adults. Contributions to this shift came from the US sociology of the 1940s - 1960s (as we will see in the next paragraph), and also from psychology.

The 1950s marked the evolution of the psychological theories on the development of identity in adolescence and youth, in particular through the work of Erik Erikson $(1950,1968)$. The author's theorisation was inscribed in a tradition of analysis and problematisation of

\footnotetext{
${ }^{3}$ For an overview on these further elaborations, see Leccardi and Feixa 2010.
} 
adolescence and youth age within the psychological and psychoanalytical field that can be traced back to the beginning of the twentieth century ${ }^{4}$. However, Erikson's analysis introduced an important and innovative element to this discourse, since it connected the formation of individual identity to social context and the specific features of modern society. Its main analytical objective was to describe the characters of identity construction during youth age and adolescence in the modern society. Therefore his approach made room for the recognition of the social and cultural situation of all processes of identity construction and also of the inner characters of youth. From this point of view, Erikson's reflections seem to partly escape from the main tendency to extrapolate data from the observation of youth and young people in Western societies (or, more in detail, in US society), and to apply them to a universal definition of the typical traits and the typical psychological process of youth as such. This tendency to overgeneralise seemed to characterise the psychological tradition in youth studies until that time, and was firstly criticised and countered by the US anthropologist Margaret Mead, in her seminal work on adolescence in Pacific societies (Mead 1928).

In Erikson's analysis, puberty/adolescence and youth are two of the eight stages in which the path of personal and psychological development and individual life are divided. During these two stages the individual elaborates his/her personal identity, interiorises the social norms, rules of behaviour and abilities that are necessary to inhabit the adult social world, and defines his/her social position. These stages are marked by an intense effort in the elaboration and negotiation of identity and their proper boundaries coincide with the resolution of this "identity work": they come to an end when the subject finds a point of equilibrium in the relationship between the self and the others, the self and the social world. According to the author's view, the achievement of maturity and the assumption of adult roles in complex societies (this means societies that are characterised by pluralism and a high degree of social specialisation) requires an interim period of exploration between childhood and adulthood. For this reason, adolescence and youth age in modern societies are characterised by a "psychosocial moratorium", a period in which young people are allowed more experimentation, the assumption of reversible choices, and a partial freedom from the constraints and rules which structure social order and cohesion in the mainstream and adult society. The duration of the "moratorium" - and therefore the extension of adolescence and youth - depends on the degree of social differentiation and increases with increasing social complexity. Moreover, with the growth of social complexity the choices and possibilities that open up to each individual, and with respect to which individuals have to learn to locate themselves, multiply. As a result, the elaboration of individual identity becomes more complex and requires more personal and social resources. Therefore, it becomes increasingly likely that adolescence and youth would be accompanied by a "crisis of identity", that is a difficulty in processing identity, a time of trouble and distress which marks the psychosocial development of the young subject and reveals a conflict between different roles and expectations that he or she is called upon to cope with.

Erikson's theory advanced some elements that will be very important in the subsequent studies on youth condition and youth cultures: above all, the key concept of identity. To some extent the theory also anticipated some of the key issues of the current debate, especially the reflections on the processes of negotiation of identity and the cultural work that young people

\footnotetext{
${ }^{4}$ See for instance the seminal work by G. Stanley Hall (1904).
} 
are called to carry out in order to cope with the growing uncertainty that characterises contemporary societies.

\subsection{The structural-functionalist paradigm and the discovery of "youth culture"}

Other fundamental contributions to the study of youth from the 1940s to the 1960s come from sociology, at that time dominated by the structural-functionalist paradigm mostly developed in the United States. The most prominent scholar within this theoretical approach was Talcott Parsons (1942, 1950, 1962), who, as well as Shmuel Noah Eisenstadt (1956), dedicated particular attention to youth cultural practices and to youth as a social category. It is within this paradigm that the phrase "youth culture" was coined (Parsons 1942, 1950), defined as the culture developed among a group of peers, the cultural world of young people and adolescents which is independent and even opposite to the adult one.

The author's engagement with the topic was firstly motivated by the observation of this new phenomenon (the existence and visibility of a youth who expresses inverse values to the adult world), and by its association with the theoretical core question of structural-functionalism, that is the reproduction of social order.

Following Parsons, youth culture is characterised by "a compulsive independence of, and antagonism to, adult expectations and authority", combined with "a compulsive conformity to the peer group" and a tendency to "romanticism", that is the "unrealistic idealisation of emotionally significant objects" (Parsons 1950: 378-379). Young people refuse the culture of adult society and develop their own values, mostly articulated around hedonistic orientations (that is shown for instance by the relevance of consumption and leisure activities), and around the refusal of the ethic of productive work and conformity to routine and responsibility (shown by irresponsible behaviour). Here it is important to notice that in its first formulation under the structural-functionalism paradigm, youth culture was described as a homogenous whole, encompassing all young people without distinctions. This will be one of the main elements that will be criticised by later analyses in youth studies.

These apparently deviant characters of youth culture were met with concern by the author, since they seemed to pose a threat to social order. At the same time, the emergence of a set of behaviours, values and orientations that deviated from the adult norms were seen as the reflection of the profound changes in the socialisation processes in modern society, and therefore they were linked to the broader issue of the changing dynamics of social reproduction. The family was seen as no longer able to keep its primacy in the socialisation processes or to assure the full intergenerational transmission of knowledge, abilities and social roles. Other socialisation agencies acquired an important role: among them, the educational system on the one hand, and the peer group on the other. The attention went to this last and newer relational space, which was recognised as a fundamental space of socialisation by functionalist analysis. Following this view, the peer group was seen as an intermediate agency that facilitates detachment from the particularistic roles and orientations proper of the childhood, and instead fosters the development of universalistic orientations, of secondary relationships and of the necessary capabilities for undertaking the complex social roles which mark the entrance into adulthood. Moreover, the fact that the peer group is a space mostly exempt from family and social control was seen as coherent with the socialisation function, 
since this partial freedom assures the testing of social roles during adolescence and youth. A "licence" moment that, in line with the analysis in psychological sciences, was seen as fundamental for the subsequent functional and effective integration into adult life and society. As a counterpart, the lack of social control entails the formation of youth culture as deviant and in opposition to adult culture, and allows its reproduction and autonomy.

The structural-functionalist analysis expressed an ambivalent position toward youth culture, which was alternatively seen as functional to or threatening toward social order. More in detail, within this paradigm two positions can be identified in relation to the issue of the impact of youth culture on social organisation or disorganisation.

On the one hand, the authors mentioned to this point, Parsons and Eisenstadt, despite starting from an apprehensive account of the unadaptive or deviant culture of young people, tended to highlight its temporality and eventual dissolution into the mainstream culture. Their analysis remarked the adaptive function of this temporarily non-conformist posture, which would eventually end up being reabsorbed by the system. It was indeed interpreted as a functional element of society, primarily orientated to the overall aim of social integration.

On the other hand, authors like James Coleman (1961) focused on the risks of social deconstruction that seemed to proceed from the broad diffusion of a youth culture based on a refusal of integration within dominant social values. For instance, in his work "The adolescent society" (1961) Coleman provided a picture of the cultural world of adolescents as highly separated from that of the adults, and described a strong division between the adult and young generations. In his eyes, this cultural gap would likely increase and result in a "conflict between generations", rather than being solved through the subsequent process of integration into adulthood, especially in societies characterised by rapid social change.

\subsection{Critical sociology on youth movement and counter-culture}

The emergence of youth cultures and movements in the 1950s and 1960s was interpreted in a different way by the other theoretical position within the sociological debate of that period, which is known as "critical" or "radical sociology". While the structural-functionalist analysis - which constituted the main theoretical trend in US sociology - was built around the conservative concern for social integration and reproduction, the authors engaged in this second approach articulated their research around the critical assessment of capitalist society and the possible directions towards a transformation of the power and cultural structures which sustain it. The works on youth elaborated within this perspective (Goodman 1956; Roszac 1968) focused on what they named "counter-culture", to indicate those alternative youth cultures which emerged in European and US society and became visible in the public sphere in the late 1950s and throughout the 1960s. These cultures - for instance "beat culture", "hippies", and the cultures related to student and anti-war movements - were the expression of a portion of (mostly middle class) youth advancing an explicit political and ideological stance against the cultural models of the capitalist society. A critical stance whose main expression, following the analysis of the critical/radical sociology, was the open refusal of the values and social objectives of an affluent, consumerist society, such as for instance the imperative to consume, economic growth and competition, orientation towards individual wealth, the grammar of social prestige and respectability, and the ruling bureaucratictechnocratic view. In this view, young people engaged in counter-cultural movements 
inhabited a position of nonconformity to both the socially established objectives and the rules that guide their attainment. For that reason, they should be recognised as different from deviant subjects, which means subjects who reject the system trying to achieve socially legitimate objectives through socially illegitimate means. They expressed dissatisfaction with the rules of the "system"; they did not want to play the game and preferred to withdraw from it. For radical sociology, this dissenting position would entail a strong critical stance against society, and youth counter-culture would have the makings of a deep cultural and political transformation of society. However, some doubts were cast over its capacity to actually display its potential and to become an effective transformative movement. On the one hand, these studies showed that young people participating in counter-culture experimentation try to construct alternative forms of relationships, community organisation, new ways of living and new identities. On the other hand, the authors warned against the risk that the attitude of refusal which lies at the core of counter-culture would dissolve into a new shape of conformism, preventing counter-culture from giving rise to mature political movements.

In conclusion, the youth and student movements that arouse in Europe and the US in the 1950 s and 1960s captured the attention of sociologists and social scientists. The two theoretical positions which animated the sociological debate of the period gave opposite accounts of this phenomenon, and more broadly of the role of youth and of youth cultures in society. Structural-functionalism looked at youth culture as a deviant expression of the new cultural independence of youth, which was nevertheless likely to be reintegrated into the mainstream society. In this view youth culture tends to have a conservative function (at least when the normal mechanisms of social reproduction are at play and social change is not too fast). Conversely, critical sociology envisaged a potential for innovation and transformation in youth counter-culture. Therefore this second approach reinvigorates the idea of youth as privileged agents of social and cultural innovation that was already at the core of Mannheim's theory. However, in the works of radical sociologists this connection between youth and social transformation was often advanced on the basis of an ideological position rather than on attentive empirically situated analysis, and this element seems to constitute one of the main limitations of this research approach.

\subsection{The Centre for Contemporary Cultural Studies in Birmingham and the concept of subcultures}

A fundamental contribution to the analysis of youth cultures are the studies elaborated at the Centre for Contemporary Cultural Studies (CCCS) at the University of Birmingham. In the second half of the 1970s and the early 1980s, CCCS produced a series of influential works on youth and popular culture in the British context, that opened up a new field of research into what was named "youth subcultures" and became a reference point for further studies on youth at the international level. Among the CCCS's production, the seminal work edited by Stuart Hall and Tony Jefferson (1975), as well as works by John Clarke (1973), Phil Cohen (1972), Paul Corrigan (1979), Christine Griffin (1985), Dick Hebdige (1974, 1979), Tony Jefferson (1973), Angela McRobbie (1978, 1980) and Paul Willis (1977), are worth mentioning.

Starting from Marxist and Gramscian perspectives, the research of the Birmingham school was articulated around questions related to the changing class structure and the new dynamics 
of mass culture in Britain, where a variety of highly stylised and spectacular juvenile groups (e.g. mods, punks, skinheads, and crombies) emerged in those decades. The term "subcultures" was introduced to take account of these forms of cultural expression of youth, and of working-class youth, in particular. The working-class youth subcultures were interpreted in relation to their specific class and generational/age position, and also in terms of their relationship both to their parents' culture and to the dominant, middle class culture. They were understood as strategies to cope with the working-class youth's social location and the contradictory expectations, resources and constraints it entailed. Moreover, they were read as forms of resistance to the hegemonic culture, which was meant to coincide with middle class and bourgeois culture and to be mostly based on mass consumption.

Following the analysis elaborated within the Birmingham school, young people from the working class were subject to the market and the imperative of consumerism, imposed by the dominant culture. However, they shared a condition of economic marginality that made consumption and achievement of the dominant social goals particularly difficult for them. At the same time, they were also engaged in pursuing class goals, which they had in common with their parents' culture, and in resistance to the dominant culture. However, due to the rapid changes in the socialisation processes and in social and cultural transmission between generations, young people belonging to the working class seemed to elaborate different solutions to the goals and contradictions associated with their structural position when compared to their parents.

Scholars involved in the CCCS pay special attention to the usage and signifying of material objects and cultural goods, such as music, leisure activities, dress styles and other elements of appearance, and to consumption choices. They developed a semiotic and qualitative analysis of these elements, whose main objective was decoding their meanings through adopting an emic perspective. Their analysis showed that working-class youth adopt elements (values, beliefs, behaviours, choice of material goods) from both their class culture and the dominant culture, combining and reassembling them in innovative, original ways. For instance, they take cultural or material goods and reinsert them in a different context, subverting or reversing their origins and taking for granted their meanings, in a process labelled "bricolage" by anthropologists (Levi-Strauss 1962). Therefore in the analysis of the Birmingham school, style seemed to reify and signify the intangible elements of class cultures and the contradictions inherent to adult class structure. The creation of a particular juvenile style by young working-class people, through the process of appropriation and reinterpretation of the cultural goods they have access to, is seen as a means by which they attempt to manage these contradictions, and as a response to their subordinated structural position. Therefore, for these scholars the emergence of youth subcultures is rooted in the situated experience of working class youth, and is connected to the material and concrete problems they have to face due to their class and age position. However, youth subcultures represent a response that is placed completely at the symbolic level. Young working-class people attempt to find solutions to their class experience and the requirements of youth age (e.g. uncertainty and luminal position, construction of the personal and social identity) through mechanisms of symbolic negotiation, ultimately through the manipulation of the meanings of material objects and cultural goods, the construction and display of spectacular body styles and consumption styles, which are easily identifiable as signs of rebellion and mark belonging to an alternative cultural world. For that reason, youth subcultures are described as "magic solutions" to social and structural contradictions (Ph. Cohen 1972). The most visible aspects of youth subcultures (spectacular and anti-conformist styles) deploy a symbolic challenge to social order, represent 
a "noise" (Hebdige 1979), introduce temporary confusion and disturbing elements into the mainstream culture and the social system. However, they ultimately do not come to be a real element of transformation, since they are cooped and commodified by the market and consequently lose their disruptive potential.

This does not mean that youth subcultures should be dismissed as apparent, illusory expressions of a "false consciousness" of young working class people (like in the traditional Marxist perspective). Symbolic and cultural forms of resistance are not deemed less important than other more traditional, political forms of resistance.

One of the most insightful elements of the Birmingham school's approach is the aim to take youth subcultures seriously and on their own terms, without dismissing them as ephemeral expressions of youth non-conformism or as forms of "juvenile deviance" like most of the previous studies on youth cultural practices and behaviours. As noted by Griffin: "The youth subculture project treated (...) working class youth cultural practices as imbued with meaning and political significance, as worthy to be studied in their own terms, and as potentially creative rather than inherently destructive or of minimal cultural value" (Griffin 2011: 4).

This kind of orientation marked a strong distance between the Birmingham framework and the previous attempts to make sense of youth as cultural agents. It provided later youth research with crucial keys for understanding contemporary youth cultural practices, which increasingly rely on the symbolic level and are articulated more around expressive behaviour, and less on direct and explicit political commitment.

Moreover, from the methodological point of view the CCCS approach entailed a special focus on the empirical grounding of any account of the cultural production of youth: research within the CCCS framework pursued a comprehensive understanding of youth cultural worlds and production, drawing on ethnographic methods and on semiotic analytical tools.

Another important element at the core of the Birmingham approach, which marked the difference from previous approaches and which would be very influential on further analysis on youth, is the attention for the differentiation of youth cultural expressions. A key understanding at the basis of CCCS analysis is the idea that there is not a monolithic youth culture, but different youth subcultures that vary mostly in relation to class. In this sense, the CCCS approach recovered the idea of the plurality and the coexistence of different youth cultures within contemporary society, which was important in Mannheim's theory but was misplaced in later sociological analysis, and which has such a prominent role for understanding youth condition and cultural production in the contemporary scenario.

Last but not least, the CCCS scholars inaugurated the research on leisure time and consumption as central elements of youth studies.

For all these reasons, the analytical framework developed by CCCS scholars has been very influential in youth studies of the subsequent decades. It has also been subject of a great number of critical revisions, which highlighted some of its limitations, bias and critical points, which are in turn the subject of the next subsection.

\subsection{Critics of the Birmingham school and the "post-subcultural" turn}


A first, fundamental criticism of the Birmingham school regarded the minimal attention paid to gender, sexual, ethnic and geographical differences among young people. As already explained, the focus on the class dimension and the interest for the issue of resistance to bourgeois cultural hegemony, led the CCCS scholars to underestimate differences other than class and therefore to focus on mostly male, white, heterosexual working-class youth subcultures in Britain. Despite the importance of the feminist movements in the 1960s and 1970s in Britain, that is within the socio-political context in which subcultural studies developed, CCCS research underestimates female youth subcultures, with but a few notable exceptions (Griffin 1985; Mc Robbie 1978, 1980; McRobbie and Garber 1975). More broadly, until the mid-1980s research involving young people was informed by a wellestablished gender-blindness (Griffin 1987, 1993, 2011) and the experience and culture of girls and female teenagers were treated as marginal, when not invisible. Similar criticisms have been raised with reference to the dimensions of race and ethnicity: at a time of emergence of antiracist and black movements, black youth received little attention in early subcultural studies, outside the later work "The Empire strikes Back: Race and racism in 1970s Britain" (Race and Politics Group 1982). Another important omission that has been noted in CCCS research, refers to the impact of gay culture on British post-war youth culture. The Birmingham school was also criticised for overestimating the political significance and the transformative potential of (white, male, heterosexual) working-class youth subcultures. Several authors cast some doubts on the accuracy of the interpretation of youth subcultures as forms of class resistance - a core element of the CCCS' analysis- and on its generalisation and applicability to contemporary youth cultural processes.

Another criticism regards the CCCS' tendency to make reference to youth subcultures as they were clearly delimitated entities, a collective expression of circumscribed sectors of the youth population. From the 1980s, this vision has gradually lost substance and has given way to a more fluid conception of youth cultural practices, which have been increasingly understood in terms of dynamic and individualised processes of negotiations and identity expression, rather than the expression of stable collective identities. More broadly, the possibility of the CCCS framework to fit into the analysis of youth cultures in late modernity has been put into question 5 .

This critical questioning entails a double aspect. The first reason is that the analytical framework articulated to give account of youth cultural practices in the British society of the 1970s, has not proved to be incisive in understanding youth conditions under the late capitalism.

The second reason has to do with a more subtle shift in the passage to late modernity, which is not directly related to the material conditions and lived experiences of young people, but to the condition of knowledge production and the change of paradigms in the social sciences. As Bennett noted (2011a, 2011b) the "cultural turn" in social sciences (Jameson 1998; Nash 2001) had consequences also on youth studies. It introduced a new conception of "culture" as a fluid system of meanings rather than as an "island", a fixed object, a reified conglomeration of habits, values and material objects associated with a definite social group. It "recast culture

\footnotetext{
${ }^{5}$ The consequences of this shift on contemporary youth studies will be the subject of detailed analysis in the next chapter.
} 
as a dynamic and participatory process through which social actors play an active role in shaping their everyday socio-cultural environment" (Bennett 2011a: 28).

As a consequence, there had been a growing interest in the cultural processes involved and reflected in the everyday lives of young people. The analysis of youth cultural practices has no longer been confined to spectacular styles, to specific class-based subcultures or to counter-cultures that are an expression of the dissent of specific youth groups and sectors, it has rather tended to encompass the everyday lived experiences and cultural practices of a variety of youth subjects.

The critical reasoning around the limitations of the Birmingham conceptual framework and the new tendencies in conceiving youth cultural practices constitute the core elements of the "post-subcultural" approach (Bennett 1999, 2000; Bennett and Kahn-Harris 2004; Hodkinson and Diecke 2007; Miles 2000; Muggleton 2000; Muggleton and Wienzierl 2003; Redhead 1990; Redhead et al. 1997): a body of work that emerged during the 1990s and early 2000s, and that "argued that the concept of subculture, as this had been applied to the study of stylebased youth cultures during the previous 25 years, had become redundant as a conceptual framework" (Bennett 2011b: 493) ${ }^{\mathbf{6}}$. Therefore, research on youth cultures in the 1990s and early 2000s had been dominated by a critical dialogue around the continuing validity, or not, of the concept of subculture (Bennett 2005; Blackman 2005; Hesmondhalgh 2005; Shildrick and MacDonald 2006).

\section{References to chapter 2}

Abrams, P. (1982) Historical Sociology. Shepton Mallet, Open Books.

Anderson, N. (1923) The Hobo: the Sociology of the Homeless Man. Chicago, The University of Chicago Press.

Bennett, A. (2011a) The Continuing Importance of the "Cultural" in the Study of Youth. Youth Studies Australia, 30 (3): 27-33.

Bennett, A. (2011b) The Post-Subcultural Turn: Some Reflections 10 Years On. Journal of Youth Studies, 14 (5): 493-506.

Bennett, A. (2005) In Defense of Neo-Tribes: A Response to Blackman and Hesmondhalgh. Journal of youth studies, 8 (2): 255-259.

Bennett, A. (1999) Subcultures or Neo-Tribes?: Rethinking the Relationship between Youth, Style and Musical Taste. Sociology, 33 (3): 599-617.

\footnotetext{
${ }^{6}$ For a critical review of this strand of research see Bennett $2011 \mathrm{~b}$.
} 
Bennett, A. and Kahn-Harris, K., eds. (2004) After Subculture: Critical Studies in Contemporary Youth Culture. Basingstoke, Palgrave.

Blackman, S. (2005) Youth Subcultural Theory: A Critical Engagement with the Concept, its Origins and Politics, from the Chicago School to Postmodernism. Journal of Youth Studies, 8(1): 1-20.

Clarke, J. (1973) The Skinheads and the Study of Youth Culture. Working paper, Centre for Contemporary Cultural Studies, University of Birmingham. Downloaded at http://www.birmingham.ac.uk/Documents/college-artslaw/history/cccs/stencilled-occasionalpapers/1 to8and11to24and38to48/SOP23.pdf (Last accessed 28-04-2014).

Cohen, A. (1955) Delinquent Boys: the Subculture of the Gang. Glencoe, The Free Press.

Cohen, P. (1972) Subcultural Conflict and Working Class Community. Working papers in Cultural Studies 2. Centre for Contemporary Cultural Studies, University of Birmingham.

Comte, A. (1830-1842) Cours de philosophie positive, vol. 1-2. Paris, Hermann.

Corrigan, P. (1979) Schooling the Smash Street Kids. London, Macmillan.

Cressey, P. (1932) The Taxi-Dance Hall: a Sociological Study in Commercialized Recreation and City Life. Chicago, The Chicago University Press.

Dilthey, W. (1883) Selected Works, Vol. I, Introduction to Human Sciences. Princeton, Princeton University Press

Eisenstadt, S. N. (1956) From Generation to Generation: Age Groups and Social Structure. Glencoe, Free Press.

Erikson, E. (1950) Childhood and Society. New York, Norton.

Erikson, E. (1968) Identity: Youth and Crisis. New York, Norton.

Griffin, C. (2011) The Trouble with Class: Researching Youth, Class and Culture beyond the 'Birmingham School'. Journal of Youth Studies, 14 (3): 245-259.

Griffin, C. (1993) Representations of Youth: the Study of Youth and Adolescence in Britain and America. Oxford, Polity Press. 
Griffin, C. (1987) Youth Research: Young women and the "Gang of Lads" Model. In: J. Hazekamp, W. Meeus and Y. Poel (eds.) European Contributions to Youth Research. Amsterdam, Free University Press.

Griffin, C. (1985) Typical Girls? Young Women from School to the Job Market. London, Routledge and Kegan Paul.

Goodman, P. (1956), Growing Up Absurd: Problems of Youth in the Organized Society. New York, Vintage Books.

Hall, G. S. (1904) Adolescence: its Psychology and its Relations to Physiology, Anthropology, Sociology, Sex, Crime, Religion and Education. New York, Appleton.

Hall, S. and Jefferson, J., eds. (1976) Resistance through Rituals: Youth Cultures in Post-War Britain. London, Hutchinson.

Hebdige, D. (1974) The Style of the Mods. Working Paper, Centre for Contemporary Cultural Studies, University of Birmingham. Downloaded at http://www.birmingham.ac.uk/Documents/college-artslaw/history/cccs/stencilled-occasionalpapers/1 to8and11to24and38to48/SOP20.pdf (Last accessed 28-04-2014).

Hebdige, D. (1979) Subculture: The Meaning of Style. New York \& London, Routledge.

Hesmondhalgh, D. (2005) Subcultures, Scenes or Tribes? None of the Above. Journal of Youth Studies, 8 (1): 21-40.

Hodkinson P. and W. Deicke (eds.) (2007) Youth Cultures: Scenes, Subcultures and Tribes. New York, Routledge.

Jameson, F. (1998) The Cultural Turn: Selected Writings on the Postmodern, 1983-1998. Brooklyn, Verso.

Jefferson, T. (1973) The Teds: A Political Resurrection. Working Paper, Centre for Contemporary Cultural Studies, University of Birmingham. Available at http://www.birmingham.ac.uk/Documents/college-artslaw/history/cccs/stencilled-occasionalpapers/1to8and11to24and38to48/SOP22.pdf (Last accessed 28-04-2014). 
Leccardi, C. (2002) Generazioni e genealogie femminili nel Mezzogiorno. In Leccardi, C. (ed.), Tra i generi. Rileggendo le differenze di genere, di generazione, di orientamento sessuale. Milano, Guerini: 47-69.

Leccardi, C. (2000). Tempo e generazioni. Adultità, 12: 43-51.

Leccardi, C. (1996). Futuro breve. Le giovani donne e il futuro. Torino, Rosenberg \& Sellier. Leccardi, C., and Feixa, C. (2010) The Concept of Generation in Youth Theories. Revista de Pedagogie, 58(4): 7-22.

Levi-Strauss, C. (1962) La pensée sauvage. Paris, Plon.

Mannheim, K. (1923) The Problem of Generations, in K. Mannheim, Essays on the Sociology of Knowledge, edited by P. Kecskemeti. London: 265-292.

Mannheim, K. (1943) The Problem of Youth in Modern Society. In Mannheim, K., Diagnosis of Our Time: Wartime Essays of a Sociologist. London, Routledge and Kegan Paul.

McRobbie, A. (1978) Working Class Girls and the Culture of Femininity. In Women's Studies Group, Women Take Issue: Aspects of Women's Subordination. London, Hutchinson.

McRobbie, A. (1980) Settling Accounts with Subcultures: A Feminist Critique. Screen Education 34: 37-49

McRobbie, A. and Garber, J. (1975) Girls and Subcultures: An Exploration. In: Hall, S. and Jefferson, J., eds. (1976) Resistance through Rituals: Youth Cultures in Post-War Britain. London, Hutchinson: 209-222.

Mead, M. (1928) Coming of Age in Samoa; a Psychological Study of Primitive Youth for Western Civilization. New York, Blue Ribbon Books.

Merton, R. K. (1938) Social Structure and Anomie. American Sociological Review 3: 872682.

Miles, S. (2000) Youth Lifestyles in a Changing World. Buckingham, Open University Press. Muggleton, D. (2000) Inside Subculture: The Postmodern Meaning of Style. Oxford, Berg. Muggleton, D. and Weinzierl, R., eds. (2003) The Post-Subcultures Reader. Oxford, Berg. 
Nash, K. (2001) The 'Cultural Turn' in Social Theory: Towards a Theory of Cultural Politics. Sociology, 35 (1): 77-92.

Park, R. E, Burgess, E. W. and McKenzie, R. (1925) The City. Chicago, The University of Chicago Press.

Parsons, T. (1942) Age and Sex in the Social Structure of the United States. American Sociological Review, 7 (October): 604- 616.

Parsons, T. (1950) Psychoanalysis and the Social Structure. Psychoanalytical Quarterly, 19: 371-384.

Parsons, T. (1951) The Social System. Glencoe, Free Press.

Parsons, T. (1962) Youth in the Context of American Society. Deaedalus, winter: 97-123.

Race and Politics Group (1982) The Empire Strikes Back: Race and Racism in 1970s Britain. London, Hutchinson.

Redhead, S. (1990) The End-of-the-century Party: Youth and Pop towards 2000. Manchester, Manchester University Press.

Redhead, S., Wynne, D., and O’Connor, J., eds. (1997) The Clubcultures Reader: Readings in Popular Cultural Studies. Oxford, Blackwell.

Roszac, T. (1968) The Making of a Counter Culture. Reflections on the Technocratic Society and its Youthful Opposition. New York, Doubleday \& Company.

Shaw, C. (1930) The Jack Roller: a Delinquent Boy's Own Story. Chicago, The University of Chicago Press.

Shildrick, T. and MacDonald, R. (2006) In Defense of Subculture: Young People, Leisure and Social Divisions. Journal of Youth Studies, 9 (2): 125-140.

Thomas, W. (1923) The Unadjusted Girl: with Cases and Standpoint for Behavior Analysis. Boston, Little Brown.

Thrasher, F. (1927) The Gang: a Study of 1.313 Gangs in Chicago. Chicago, The University of Chicago Press. 
Whyte, W. F. (1943) Street Corner Society: The Social Structure of an Italian Slum. Chicago, University of Chicago Press.

Willis, P. (1977) Learning to Labour: How Working Class Kids Get Working Class Jobs. Farnborough, Saxon House. 


\section{Contemporary studies on youth and youth cultures in European and Western contexts}

\subsection{Transition to adulthood}

As mentioned earlier in the introduction to this paper, the history of the study of youth in sociology can be divided into two main areas of analysis since its very inception. The first approach focuses on a structural examination of the process of transition to adulthood, while the second focuses on youth cultures (Furlong, Woodman and Wyn, 2011). As for the first, a number of issues have been at the core of structural analysis of the transition to adulthood, namely economic, political and social conditions, which have been considered in order to assess whether they favour such a transition or are an obstacle to it. Social, economic and political circumstances can indeed favour elements considered to facilitate the transition to adulthood, such as education, successful job search and balanced relationships with the family of origin and political participation. As for the second approach, the core issues have been identified also thanks to the strong influence of the Birmingham-based Centre for Contemporary Cultural Studies (CCCS) during the 1970s. Since then, youth has been investigated under a number of aspects: issues such as the production and consumption of culture, and the presence of styles underlining belonging to a specific subcultures (teddy boys, punk, mods, skinheads) have been at the very core of the research interests of sociologists, who were preoccupied with the issue of identity and belonging as an expression of resistance to domination and domineering culture, and to the social stratification and organisation in post-WWII Great Britain. In such environments, the so-called "spectacular subcultures" developed.

The two approaches to the study of youth ${ }^{7}$ are intertwined with the economic and social changes that affected post-WWII Europe. Indeed, since the 1970s, the growing unemployment rate has influenced to a great extent the biographies of young people in Europe, therefore boosting the scholarly interest for the study of transition to adulthood. Such a reinvigorated scholarly environment has been conducive to very innovative and even selfcritical lines of inquiry, whereby scholars started to question the very concept of transition (Evans and Furlong, 1997; Wyn and White, 1997). In the context of Youth Studies, the influence of the School of Birmingham is still strong, despite increasing criticism. In particular, such influence is evident when it comes to the studies of youth subjectivities, youth values, youth reactions to social changes, and with a particular focus on youth cultures.

During the 1990s, the study of youth received new stimuli bringing to the forums of discussion new debates and reflections about the process of transition to adulthood. The globalisation of economy and the social transformation descending from it are powerful engines of change. The so-called industrial economy and society is replaced with a push towards services and de-commodified economy, with significant consequences for the labour market. Indeed, long-term or permanent job opportunities are increasingly replaced by short-

\footnotetext{
${ }^{7}$ It is important to underline the fact that the two approaches have adopted different methodologies in the study of youth conditions. The structural approach has indeed utilised quantitative methods, whereas the cultural approach has mainly deployed qualitative methods, such as ethnography.
} 
term and precarious job opportunities, which have a remarkably strong impact on youth in transition to adulthood. In addition to difficulty of accessing the job market, and also resulting from this, higher education became a popular choice. This context has had a very strong impact on youth biographical transition to adulthood, which the scholars tackle and examine.

Indeed, previous to the changes described above, Fordist societies had been characterised by a rather linear transition to adulthood. According to Modell, Furstenber e Hershberg (1976), in Fordist societies, access to adulthood is marked by four elements, two taking place in public life and two in the private sphere, namely the end of education and consequent access to the job market, and the abandonment of the parents' house and the creation of an independent family ${ }^{8}$. These four markers of adulthood were valid for a whole generation.

In post-Fordist societies, social, economic and demographic ${ }^{9}$ conditions significantly impacted the linear model of transition to adulthood, to the point that scholars pointed out a new social phenomenon, namely prolonged youth (Cavalli and Galland 1996). Such extended youth is caused by the prolongation of education and time spent at the parents' house ${ }^{10}$. Scholarly reflections on this 'new' transition to adulthood have also been deeply influenced by those studies investigating the so-called late modernity, whose central characteristic is an ontological uncertainty. Such studies then resonate with Giddens (1991), Beck (1992), and Bauman's (1998) reflections on the 'risk society', increasing mistrust among citizens, social actors and between those and institutions, growing individualisation and loneliness, frailty of political institutions, and with Rosa's (2005) notion of an 'accelerated society', whereby new technological developments 'speed up' social time. These abrupt changes and transformations make the contemporary transition to adulthood uncertain, unpredictable and precarious. In particular, scholars have highlighted its extension and fragmentation (Galland 1996), as youth transitioning to adulthood are not only delaying choices but those choices are often not conducive to a consistent profile. The markers of transition are de-synchronised, they do not unfold one after the other and there are long pauses between. In summary, because of such fragmentation, youth are building on non-permanent choices, which are made but often repealed afterwards, with the result of defining inconsistent biographies whose responsibility is solely to the (lonely and unsupported) individuals themselves (Du Bois-Reymond, 1998; Furlong and Cartmel, 1997). The overall scientific outcome of this perspective on the transition to adulthood consists of a new take on youth, which is not merely considered as a stage, step a phase of life anymore but as a condition per se (Cavalli, 1980).

Time is considered to be a crucial element to this renovated perspective on youth, a condition on its own (Cavalli 1985). During the era of modernity, people lived with some certainties about time, which was considered to be a linear dimension subjected to the individuals' control (Leccardi, 2009). In such a context, the individual biographical time unfolded harmoniously with the unfolding of the different stages of life. Thus, for young people the dimension of future represented the time of fulfilment of life projects and of identity

\footnotetext{
${ }^{8}$ This model of transition was further elaborated by Galland (1996), who added a fifth marker of the transition to adulthood that is becoming parents.

${ }^{9}$ Since the 1970s, in Western countries birthrate has increased deeply affecting the relationship between young and old people.

${ }^{10}$ Western Countries are affected by this new phenomenon in a different way: in Southern Europe (Italy, Spain, Portugal, Greece) the 'prolongation of youth' is more prevailing than in Northern Europe.
} 
definition. The dimension of the present time was considered important because an evidence of the individual's predisposition for those projects and the identity that would be fully defined in the future.

In the era of late modernity, the relationship between biographical time, life projects and identity definition changes. Time in late modernity is not linear, but fragmented, accelerated and uncertain. Life projects 'run out' of time and are often completed in the present, as their future completion is uncertain and precarious. Long-term stability is replaced with short-term uncertainty. In this context, young people are those who suffer the most. Their subjective biographies and professional profiles are marked by new and previously unknown obstacles to a linear transition to adulthood.

However, as efficaciously ascertained by Leccardi (2005), uncertainties about the future do not lead to an 'absolutism of the present', whereby every act and choice is fully experienced and completed in the present. Given the precarious nature of the future, young people often consider the present to be an additional opportunity for action and they advance a number of strategies to balance such precariousness. The risk of abrupt changes and turning points in professional biographies, for instance, is contrasted by putting forth alternative strategies (Du Bois-Reymond 1998). Indeed, young people seem to count on more personal resources and abilities when it comes to deploying alternative strategies quickly (Leccardi 2005), thanks to an extended time available for planning and reflection ${ }^{11}$.

It follows that richer analytical perspectives on the issue of the transition to adulthood are available today in the field of youth study, resulting from unstable social and economic environments. Such instability has also reinvigorated the study of youth cultures, and scholars have focused on young people's reactions to life choices and on the meaning young people attach to their biographies (Bennett, 1999; Brannen and Nilsen 2002; Côté 2000; Harris 2002; Threadgold and Nilan 2009). In particular, life choices and strategies contribute to moulding young people's identities face à the increasing social complexity. The overwhelming social and economic transformations of late modernity have thus had the consequence of bridging the two different approaches to the study of youth (one focused on the structural living conditions of young people and how those conditions impact the transition to adulthood, the other one focused on youth cultures), invalidating what is now perceived as a 'false binary' approach (Furlong, Woodman and Wyn 2011).

\subsection{Main trends and gaps in contemporary studies on youth cultures}

The complexity of late-modern societies requires a new approach to the study of youth living conditions and youth cultures. This is the reason why the two approaches mentioned above (one focused on the structural conditions impacting the transition to adulthood, and the other focusing on youth cultural production) are today intertwined and tightly connected. It is not coincidence then that contemporary studies focus on the impact of social and economic

\footnotetext{
11 Youth sub-groups adopt different strategies to cope with and react to the transformation of social time, and how these transformations impact on individuals' biographies. In particular, there are significant differences when it comes to how young women and young men react to such changes. On this, refer to Adam (1995), Brannen and Nilsen (2002), Camozzi (2014), Leccardi (2009), Leccardi and Rampazi (1993).
} 
changes in late modernity on the experience of youth, on youth cultures, on the meanings that young people attach to their experiences and on how young people react to their own biographical conditions and to adulthood. There are three entry points that scholars have mainly utilised in order to 'look at youth' in the late modern era. The first entry point is represented by the practices of consumption, new technologies and how young people use them, and by how young people use their leisure time. The second point of observation scholars have taken to look at youth is the political participation among young people, and the relationship that young people have with the public sphere and civil society. The third perspective scholars have adopted deals with values and identity, and also deals with the complex relationship between the local and global dimensions of young people's lives and social belonging.

\subsubsection{Leisure time, new technologies and media, and practices of consumption}

Leisure time and non-working time, education and any other related activity has become crucial to the study of youth but, above all, leisure time has deeply changed in late modernity. The very transition from a Fordist society, characterised by certain economic dynamics, to a post-Fordist society, whose economy is deeply different, has influenced not only the way in which young people use their free time, but also the very nature of it. In Fordist, industrial societies, it was indeed possible and relatively easy to separate working time from nonworking time. Today, with the de-commodification of the economy, the flexibilisation of the job market and the prevalence of services over industrial production, it is very difficult, if not impossible, to draw a rigid line of separation between the time at work and time free from it. The development and the spread of new technologies has further weakened such a separation, and more generally they contributed to change the relationships of men and women in society over time, which are increasingly accelerated. These changes have not only impacted individuals' biographies, they have also contributed to widening the gap concerning the way time is experienced by older and younger generations, thereby increasing the social distance between young people and adults (Abbott-Chapman and Robertson 2001). A prevalent idea among adults of young people's leisure time seems to emerge, which does not equate with the time spent for fun or rest, but with time wasted on inactivity. It follows that time spent with peers at shopping malls (Holloway and Valentine 2000) or in front of a laptop with no constructive goal are defined as 'time wasted', 'empty time' or the time of inactivity. The possibility of assessing that 'wasted time' as crucial time for young people (time for sharing and strengthening relationships, for social experimentation with peers and for the reinforcement of the individual identity) therefore seems to be merely ignored by adults (Abbott-Chapman and Robertson 2001).

Despite the fact that some elements are shared by a huge number of young people when it comes to the deployment of time during a prolonged youth, some relevant differences do exist among sub-groups. It is possible to distinguish such sub-groups by their levels of education, gender, ethnic identities ${ }^{12}$ and above all, age cohort (Zeijl et al. 2000) ${ }^{13}$. The element of age

\footnotetext{
${ }^{12}$ Although some scholars underline the relevance of gender and ethnic differences in defining and experiencing leisure time, empirical investigations of these issues are still few.
} 
seems to be of particular importance to the so-called 'digital natives', namely those young people born after the early 1980s, whose existence has been characterised by the presence of new media and technology. They have had particular familiarity with all those means of communication directly linked or empowered by technology, such as blogs and chats, and have witnessed the increasing presence of technology in all activities they could possibly undertake, from listening to music and playing games, to studying and working (Richardson 2006). It follows that, to this generation and its successors, the merging of different types of 'time', traditionally divided into time for work, for fun, for rest and so forth, has been crucial in defining identities and social practices (from having fun to consuming and producing culture). Young adults and young people of these generations have expanded the use their private space, making their bedroom not only a fully private space to exclude the outer world (Lincoln 2012), but also a space in which to establish new virtual contacts, and manage existing ones, with the outer world. Private space is thus merged with public space through smartphones and the Internet ${ }^{14}$.

The examination of the relationship between young people and new media is central to a number of disciplines, given its relevance and complexity: along with sociology also media studies, psychology, political science and cultural studies have engaged the issue. Nevertheless, despite such a plurality, it is possible to point out two main approaches (Collin and Burns 2009). On the one side, scholars have focused on the impact of new media on the construction of identity and on the relationships among young people. On the other side, academic attention has been devoted to the effects of new media on youth political participation.

A number of studies highlighted how new media have contributed to transforming notions of distance in space and time, thus impacting the way young people act and understand social relations (Thompson 1995). Castells (1997) even pointed out the emergence of a new type of space, called 'the space of fluxes' to highlight the relevance of immaterial relationships to young people. In this space, multiple identities can emerge and can become even richer thanks to the opportunities provided by the Internet, which does not require co-presence in terms of neither time nor space for social interaction. The opportunities provided by the Internet can significantly impact the individuals' life, and this is particularly true for young people during the process of personal growth and of social identity-building. When it comes to this issue, scholars do not agree on the positive role new technologies play. On the one hand, some scholars connect the development of web-technologies to social deviances (Buckingham 2006). On the other hand, scholars have challenged this view by advancing the hypothesis of the Internet as the venue of creative expression and expansion of the individual identity thanks to the multiple opportunities for interaction provided (Coleman and Rowe 2005). In particular, Anita Harris (2004) and Lynne Hillier and Lyn Harrison (2007) highlighted that

\footnotetext{
${ }^{13}$ Beyond these traditional aspects of social differentiation, when it comes to new media, we also have to consider a few other elements, such as the geographical location from where young people can (or cannot) connect to the Internet, the type of connection (its speed and its actual availability) and the young people's e-literacy skills (Livingstone 2006; Boyd 2008). The picture that all these aspects bring together is an important part of a broader reflection on issues such as the digital divide and its implications on youth identity and youth relationships with the older generation (Stokes et al. 2004).

14 This peculiar re-definition of the relationship between public and private space experienced by young people requires further analysis and constitutes also an important element to enhance analyses of the late modern crisis of social and political institutions.
} 
young people utilise the Internet to question dominant rhetoric and discourses, and more specifically, discourses and mainstream representations linked to gender and sexuality. In addition, young people utilising new media also question the traditional separation of private and public spheres. According to these scholars, the Internet is making young people's private lives public. Today, it is very relevant to understand the mechanisms and consequences of this process, which has to be examined with proper conceptual and analytical instruments.

When it comes to the link between the new media and youth political participation, two aspects are mainly examined. The first aspect deals with the impact (whether positive or negative) the Internet has on the quality of democracy as a form of government. Are democratic forms of government weakened or strengthened by the fact that young people can create virtual forums of discussion, activate protests through the Internet, express political orientations and even debate with political leaders thanks to the Internet? Some scholars consider the Internet as a crucial instrument to strengthen the democratic system to the point that a new expression has been advanced, namely 'e-democracy.' According to this view, the Internet has been able to reinforce and renovate young people's sense of citizenship and political participation (Montgomery et al. 2004).

The opposite view argues that the political success of new media signifies the fact that the traditional democratic system is going through a deep crisis. Despite agreeing on the strength of the impact of the Internet on youth political participation, this second position also argues that new media are very profoundly transforming politics and the notion of politics held by young people, well beyond a seeming strengthening of democratic governance. The Internet is transforming the way young people perform politics, both individually and collectively, providing them with a voice. Thus, the Internet is dragging young people out from the traditional exclusion from 'official politics' they have historically suffered (Bennett 2003).

Another key-aspect in the examination of youth deals with the practices of consumption and the use of leisure time. Leisure time is indeed the time for fun, sharing new experiences with peers and building individual identity par excellence. As mentioned above, these activities can take place in the virtual space of the Internet although consumption is another activity central to the use of leisure time (Best 2009). Since the 1980s, consumption and the practices connected to it have increasingly been associated with identity-building and are regarded as having a symbolic meaning connected to identity. This has deeply renovated the dominant perspective on consumption. Indeed, up to the 1980s consumption was mainly understood as connected with the socio-economic backgrounds young people were coming from. This epistemological turn allowed for a more informed examination of (i) those segments of the market specifically devoted to youth consumption (music, clothes...), (ii) how young people use those specific markets, and the meaning they attach to them, and (iii) the function and workings of youth consumption in late modernity, given the peculiar characteristics of this era.

According to historians, since the end of the Second World War, young people have become a specific target of production and efforts have been focused on engendering new needs and desires among youth, in order to turn them into potential customers. However, most of the sociological examination of youth consumption has focused on the consequences of consumption among young people and on the meanings that young people attach to consuming certain products. This topic has been central to the analysis of the Birmingham and 
Frankfurt Schools. In particular, the School of Frankfurt has adopted a very critical stance when it comes to capitalistic society, and highlighted the creation of 'false needs' by this youth-oriented market. Young people are thus overwhelmed by the ideological might of the dominant, capitalist culture and cannot contrast it by any means. In this picture, young people do not emerge as the most critical social actors, as they are depicted as subjected to the culture of market and consumption. Although Marxist-inspired, the School of Birmingham has highlighted the active role of young people when dealing with consumption. Although heavily influenced by the dynamics of big distribution and unable to steadily determine the objects of their desire, young people deal with consumption in an active way, as they creatively resignify the objects they consume. In this way, young people utilise objects of consumption as they prefer, utilising them for purposes of identity-building, defining (sub)cultural belongings, distinguishing themselves from values and the world of adults. As Hebdige put it (1979), the consumption and the objects of consumption can be used to advance forms of resistance. It follows that young people do not only consume cultural products, but also create culture.

The two perspectives advanced by the School of Frankfurt and Birmingham still dominate the debate, although they have contributed to the debate in different ways. The Frankfurt School has indeed somehow focused on more mainstream critical analysis of the role of the media in turning young people into passive receivers, lacking a powerful push for the examination of new fields of inquiry, whereas the Birmingham School has generated original findings, although these are at times problematic. The School of Birmingham has indeed forcefully highlighted the emergence of creative and powerful rituals of resistance through consumption, such as the boycott of MNCs (Klein 2002) or cultural jamming (Harris 2004a) ${ }^{15}$. Such a central role given to the practices of resistance has caused a number of critical reflections, which can be regrouped under the label of 'post-cultural studies', arguing that the hypothesis advanced by the School of Birmingham has become obsolete in the late modern era. In particular, the scholars of the School of Birmingham were considered to have subscribed to an 'old' understanding of society, whereby the social background of origin was overestimated in relation to age, gender and ethnic differences (Stahl 2003) ${ }^{16}$. Among the most vocal and interesting critics of the School of Birmingham, we find Sarah Thornton (1995), who examined the so-called 'club cultures', Dave Muggleton (1997), who advanced the very concept of 'post-subcultures,' and Andy Bennett (1999) and his notion of 'neo-tribes.' Bennett in particular questioned the usefulness of the concept of sub-culture, arguing that Maffesoli's (1996) notion of 'neo-tribes' was far more useful to the capture of youth living conditions in late modernity ${ }^{17}$. The foundation of Bennett's critique to the scholarship of the Birmingham School revolves around the missed understanding of the fluidity, heterogeneity and fragmentation of youth cultures today, which are no longer defined by social structures such as social class belonging, but by subjectivity.

This line of inquiry is supported and enriched by the reflections advanced by Harris (2004b), who highlights how cultural consumption needs to be contextualised. The understanding of the material context in which cultural consumption takes place is crucial to fully grasping the rationale of it. This observation is of particular interest when it comes to gendered

\footnotetext{
${ }^{15}$ This aspect will be further discussed in the next section.

${ }^{16}$ See Hodkinson's (2009) discussion of the most relevant criticisms to the School of Birmingham.

17 Bennett's work, which focused on music and music performances as a form of resistance (2000), generated a very lively debate (Hesmondhalgh 2005). For a discussion of the debate, see Debies-Carl (2013).
} 
consumption, as it helps to make sense of the huge and very diversified consumption of magazines, music and TV/radio/Internet broadcasting addressed to the female audience. Looking at the context in which such diversified consumption takes place also helps us to understand the dynamics of re-signification that young women implement in their relationship with the object they are consuming (McRobbie 1991) ${ }^{18}$.

In late modernity, an era governed by globalisation and seemingly opposed dynamics of fragmentation and concentration, youth political engagement has also changed. Of particular impact are economic transformations, which have changed youth relationships to work and, consequently, to trade-unionism and political mobilisation. In addition, political participation and mobilisations have also been transformed by emerging transnational identities and greater opportunities of connection and mobility, impacting on both the process of identity-building and the patterns of mobilisation and protest thanks to easier communication and transports (Furlong and Cartmel 1997; McDonald 1999; Bennett 2003; Best 2006). In this context, consumption is crucial and resonates with the growing relevance that the individual subject is acquiring, along with the centrality of individual desire and even hedonism when it comes to the choices and the 'style' of younger generations.

\subsubsection{Political participation, engagement and citizenship}

Since the 1980s, after a decade of lively protest movements, young people have been living in an environment characterised by a rather weak push toward political engagement. In their efforts of coping with the abrupt transformations of the world economy, young people seemed to display a growing apathetic attitude towards political and social engagement and the exercise of critical citizenship. The structural conditions that societies have been offering since the 1980s have shifted youth attention from collective action and protest to individual effort for the construction of a more consistent biographical profile, which could minimise the fragmentation between past, present and future projects.

More recently, although broad structural conditions of societies have not changed, a number of dynamics have developed and reached their apex, impacting on youth's political participation (Levine 2007; Loader 2007). In particular, scholars have noted the necessity of an epistemological renovation when it comes to the understanding of politics and what politics consists of. Indeed, it has been noted that a 'narrow' interpretation of politics, regarded as being composed of elections, party politics and trade union membership equates with 'adults' politics'. In contrast, young people's engagement with politics goes well beyond those practices, suggesting a 'broader' notion and understanding of politics. This is of particular relevance as scholars had to refine and deploy new methods and new concepts in order to be able to tackle youth political engagement ${ }^{19}$. The consequence is that today scholars

\footnotetext{
18 The study of everyday practices of consumption could represent a fertile perspective to investigate the social construction of gender and the relationship between genders in globalised societies. But this quite unexplored research issue suffers from an underestimation of consumption as sociological category.

${ }^{19}$ It is possible to distinguish four phases in academic literature examining youth political participation (Harris 2009). The first phase took place between the 1950s and 1960s and mainly focused on the patterns of political socialisation of young people, drawing on both political science and psychology. The second phase (1970s and 1980s) mainly focused on young people's participation in the processes of decision-making. Since the 1990s, during the third phase, academic literature started to focus on the notion of citizenship, understood as something having moral and ethical responsibility, well-beyond a
} 
not only need to 'look back' at well-established techniques of research, but also need to deeply innovate them. Of course, this is the case for the Internet, which provides an important platform for the expression of political preferences and for engagement (Loader 2007).

Within the literature focusing on youth political participation in democratic contexts, we can find some shared characteristics. The level of education, middle-class background and the type of political socialisation constitute some shared traits of those people within the younger generations approaching politics (Flanagan, 2009; Jennings and Stoker 2004). Nevertheless, a number of studies also point to the role that social and economic disadvantaged conditions, in which for instance the so-called 'second generations' or young people coming from disadvantaged social classes live, have in politicising younger generations (Sherrod et al. 2005).

The issue of youth political participation links to another fundamental debate, namely the one on whether 'young people' could be considered as political actors. As emphasised by Anita Harris (2009), young people enjoy a specific status of political actors, although they fail to recognise an explicit political nature to the forms of their engagement. Although this sounds quite paradoxical, young people often do not enjoy full political recognition yet (as they might not enjoy voting rights yet, or welfare rights, because the 'world of politics' and of political parties is the adults' world) and as a consequence they might not acknowledge a political nature to the activities they carry out (Vromen 2003). Finally, an additional element central to the debate on youth political engagement deals with the dichotomised representation of youth. Indeed, young people are either represented as apathetic or as the vanguard of change and protest par excellence. Such representations obscure a correct understanding of the peculiarities of youth values, practices of political participation and civic engagement.

Within the scholarship on youth and political participation, we can single out three interconnected aspects that attracted scholarly attention. The first aspect deals with future economic scenarios, from which young people will suffer personal and professional instability, prolonged dependence on the family of origin, fragmented access to full citizenship and lack of enjoyment of connected rights (welfare) ${ }^{20}$ The second aspect deals with globalisation and, in particular, with the globalisation of identities, politics and culture. The fragility of the national state (a crucial institution to the modern era) impacts on the individual identity and national belonging, generating new practices and new selfrepresentations that bridge the global and local dimensions of the political engagement. ${ }^{21}$ The third aspect deals with growing individualism caused by the weakness of those traditional forms of support and welfare, which were characteristic of the modern era and of Fordist societies. In this context, individualism generates apathy and lack of interest for the traditional forms of political engagement. This pessimistic scenario can however be questioned thanks to the emergence and spread of alternative forms of political activism, strengthened by the Internet for instance.

narrower focus on citizenship as access to civil rights. Finally, the fourth phase focused on the notions of social capital (echoing Robert Putnam's studies, 1999) to examine different experiences of civic engagement, such as volunteering.

${ }^{20}$ An example of the impact of the transformation of the job market on youth engagement is the progressive weakening of youth participation in trade unionism, perceived by young people as distant from their work experience (Carle 2003).

21 The relationship between global dynamics, local identities and cosmopolitanism will be examined in the next section. 
Finally, a last aspect which must be included deals with urban revolts as political expression. This aspect is relevant in particular if we consider the role played by urban revolts in Middle Eastern cities since late $2010 .^{22}$ Academic literature has often portrayed these revolts as isolated acts of vandalism with no clear political message (Gilroy 2002). This is particularly valid in the case of urban revolts during the 1970s and 1980s. When urban revolts re-emerged during the 2000s (in the UK and in the French banlieues), the sociological debate was again re-ignited, although mainstream interpretations were still dominant and regarded those revolts as non-political actions. However scholars have noted that this interpretation tends to overlook the political meaning of those revolts, 'washing' it and turning it into ethnic violence, violent hooliganism or irrational behaviours (Akram 2009), and the Arab Uprisings, the Gezi protests or the Euro Maidan in Kiev have quite clearly showed that there is much more politics than pointless violence in these actions.

\subsubsection{Identity and values in the local/global context}

In recent descriptions of the processes of identity creation among youth groups in the West, the treatment of the body -its construction, its treatment, its restructuring, deconstruction-; the influence of an alleged global culture cantered on the creation of transnational communities; and the influence of music, specifically rock and pop, have emerged as major axes for young populations. These cultural elements are setting primary reference markers for identity negotiation that some authors reflects the existence of a global youth. Its importance to youth cultures is determined essentially by influencing elections, they invent new ways of understanding the body and diversified transnational relations, and the possibility to participate in solidarity groups related to similar life styles.

These cultural productions -or escapes as Appadurai named it- can work as global identity markers for young people around the world. Nevertheless, young people in not Western contexts construct their identity through same adscriptions but as local groups with specific meanings and/or cultural productions. It is in these contexts, where the mixed forms of youth culture appear. Pieterse (1995) describes such hybridisation as the "creolisation" of global culture, and young people are at the forefront of his creative output. However, these expressions are not only a kind of mixture. They also produce new forms that we could designate as prefigurative. One example is the Maghraganat music in Egypt categorised as non-Western music, but also as an non-Arab (Sánchez García, 2009). Use musical traditions of both models and recreates to result this genre. The potential of the 'mestizo symbols' creates by youth cultures, appears in the juxtaposition of local forms with the forms and discourses of popular culture, driven globally. There are two senses of subjectivity in which individuals use this as narrative elements to produce their identity. First, local frames of reference produced through local cultural productions; on the other, constructed from the materials of the global popular culture, then negotiating in context the adequacy of a framework or another depending on the aims. The diversity of the global elements provides numerous points and rejection of local cultures.

\footnotetext{
22 Although the Arab Uprisings originated in non-urban settings, or in semi-urban areas far from the capital cities, it is worth noting that the revolts became uprisings and attracted international attention when they reached the capital cities.
} 
The sense of the cultural productions, their meaning and significance for the identity construction process is given in the form and content of both traditions, local and global, making highlight certain forms over others with significant creative power. Among youth cultures, this process usually occurs during the group activity (Willis, 1990), prompting the emergence of new forms and allowing both the local as opposed to state. In some cases, the materials of the alleged global youth culture can create new elements and identity ascriptions that it can be locally reaching. At same time, these cultural productions can acquire a sense of political opposition and rejection of the dominant model depending on the cultural camp. In this sense, García Canclini (1989) points out the ability to create new community ties, by these, more receptive to innovations global social agents. These form transnational communities, deterritorialised, hybrid, mestizo; that will recreate new ways to recognise and differentiate themselves from other group or individual.

In addition, the construction of youth identity is intimately connected with various perceptions of space and time according to social, economic, political and cultural specificities of local contexts. Space and time thus appear as relevant in shaping youth local/global identities, featuring the so-called youth chronotope where youth individuals and groups can meet and interact with each other and with other actors, playing performative roles that express collective memories (generational, social, cultural), narrating to Themselves and to Others their own identities and otherness, trying to resolve through this narrative activity the eternal "identity crisis" of youth (Feixa and Strecker, 2014).

The identity construction of youth could be exemplified by life stories. When young people tell their life stories, space is usually organised as a series of concentric circles that are based on the subject and its surroundings. This includes physical space: housing, domestic space, neighbourhood, local and supra national space; and social space: family, kinship network, networks of neighbours and friends, networks of institutional relations. This concentric spatial dimension creates a number of polarities: private space versus public space, civil space versus state space, and institutional space versus recreational space. Each concentric level has certain conventions and rules. For example, each level comprises specific codes of conduct acceptable only in such spaces. Body contact and gossip is normal in private spaces but unacceptable in public spaces; and body performances are normal in public spaces but inappropriate in private spaces. This is precisely one of the problems with the online social networks: there is not a clear border between public, semi-public and private space-times, a clear rule (netiquette) for an appropriate behaviour in each of the virtual walls.

The intensity of social relations is shaped by the space in which each young person conducts his or her daily life. This includes intimate areas of affective and discretionary practice, as well as open and coercive spaces, where activities take place regularly and in a hierarchical fashion. Yet sometimes the intimate space of the family can become a place of control, and public places of entertainment can become private places. The second axis is time, organised in the temporal dimensions of daily, weekly, calendar, biographical, generational and historical time. The time dimension also structures various binary oppositions. Productive time (academic or occupational functioning) is opposed to festive time, collective time to individual time, or quiet time (such as music in the room) versus noise time (at a concert or dance club). There is also a contrast between repetitive time (exercise, school and work rhythms, patterns of consumption) and time for rupture (the party, transgression, travel, freerunning) and so on. The organisation of the day, the routes of the weekend, planning travel, 
crucial moments in the life cycle, generational events, are not left to chance but are culturally elaborated by formalised rituals, reflecting the symbolic memory work of narrating a biography.

\section{References to chapter 3}

Abbott-Chapman, J. and M. Robertson (2001), Youth leisure and home: space, place and identity, Leisure and Society, 24: 484-506.

Adam, B. (1995) Timewatch: The Social Analysis of Time. Cambridge: Polity Press.

Akram, S. (2009) 'Riots' or 'urban disorders'? The case for re- politicizing urban disorders, in A. Furlong (ed.) Handbook of Youth and Young Adulthood. New perspectives and agendas, London and New York: Routledge, 313-20.

Bauman, Z. (1998) Work, Consumerism and the New Poor. Buckingham: Open University Press.

Beck, U. (1992) Risk Society. London: SAGE.

Bennett, A. (1999) Subcultures or Neo-tribes? Rethinking the Relationship between Youth, Style and Musical Taste, Sociology 33(3): 599-617.

Bennet, A. (2001) Cultures of Popular Music, Buckingham: Open University Press.

Bennett, L. (2003) Communicating global activism: strengths and vulnerabilities of networked politics, Information, Communication and Society, 6: 143-68.

Best, A. L. (2006) Fast Cars, Cool Rides: The Accelerating World of Youth and Their Cars, New York: NYU Press.

Best, A. L. (2009) Young People and Consumption, in A. Furlong (ed) Handbook of Youth and Young Adulthood. New perspectives and agendas, London and New York: Routledge, 255-62.

Boyd, D., (2008) Why youth $\checkmark$ social network sites: the role of networked publics in teenage social life, in D. Buckingham (ed.) Identity Volume, Cambridge, MA: M.I.T. Press, 119-42. 
Brannen, J. and A. Nilsen (2002) Young People's Time Perspectives: From Youth to Adulthood, Sociology 36(3): 513-37.

Buckingham, D. (2006) Children and new media, in A. Lievrouw and S. Livingstone (eds) The Handbook of New Media, London, Sage.

Carle, J. (2003) Welfare regimes and political activity among unemployed young people, in T. Hammer (ed.) Youth Unemployment and Social Exclusion in Europe, Bristol, Polity Press.

Camozzi, I. (2014), “Sempre un po' provvisoria e permanente”. Giovani cosmopoliti tra progetti di vita e tempi-spazi della metropoli, Rassegna Italiana di Sociologia, forthcoming.

Castells, M. (1997) The Information Age: Economy, Society and Culture, vol. 2: The Power of Identity, Oxford: Blackwell Publishers.

Cavalli, A. (1980), La gioventù: condizione o processo? Rassegna Italiana di Sociologia, XXI, $4,519-42$.

Cavalli, A. (1985) (ed) Il tempo dei giovani, Bologna, il Mulino.

Cavalli, A and Galland, O. (eds) (1996) Senza fretta di crescere. L'ingresso difficile nella vita adulta, Napoli: Liguori

Coleman, S. and Rowe, C. (2005) Remixing Citizenship: Democracy and Young People's Use of the Internet, London: Carnegie Young People's Initiative.

Collin, P. and Burns, J. (2008) The experience of youth in the digital age, in A. Furlong (ed) Handbook of Youth and Young Adulthood. New perspectives and agendas, London and New York: Routledge, 283-90.

Côté, J.E. (2000) Arrested Adulthood: The Changing Nature of Maturity and Identity. New York: New York University Press.

Debies-Carl, J. (2013) Are the kids alright? A critique and agenda for taking youth cultures seriously, Social Science Information, 52(1): 110-33.

Du Bois-Reymond, Manuela (1998) ““I Don’t Want to Commit Myself Yet”: Young People's Life Concepts', Journal of Youth Studies, 1(1): 63-79. 
Evans, K. and Furlong, A. (1997) Metaphors of Youth Transitions: Niches, Pathways, Trajectories of Navigations, in J. Bynner, L. Chisholm and A. Furlong (eds) Youth, Citizenship and Social Change in a European Context. Aldershot: Avebury.

Feixa, C. et al. 2002. "Movimientos juveniles: de la globalización la antiglobalización". Feixa, C., Pereira, I., Juris, J. S. (2009) Global citizenship and the 'New, New' social movements: Iberian connections. Young: Nordic Journal of Youth Research, 17 (4) 421 - 442.

Feixa, C., Romaní, O., Hakim, N., Latorre, A., Porzio, L., \& Rodríguez, A. (2010). "Spain Irregular Lives in the Southern Rim of Europe". In K. Fangen, K. Fossan, \& F-A-Mohn (Eds.), Inclusion and exclusion of young adult migrants in Europe. Barriers and bridges (pp. 17-50). London: Ashgate.

Feixa, C. (2012). Youth Cultures and Youth Work: Perspectives from the South of Europe. In Ph. Coussée, H. Williamson, \& G. Verscheldel (Eds.), The History of Youth Work in Europe. Relevance for today's youth work policy (vol. III, pp. 129-140). Strasbourg: Council of Europe Publishing.

Flanagan, C. (2009) Young people's civic engagement and political development, in A. Furlong (ed) Handbook of Youth and Young Adulthood. New perspectives and agendas, London and New York: Routledge, 293-300.

Furlong, A. and Cartmel, F. (1997) Young People and Social Change: Individualization and Risk in Late Modernity, Philadelphia, PA: Open University Press.

Furlong, A., Woodman, D. and J. Wyn (2011) Changing times, changing perspectives: Reconciling 'transition' and 'cultural' perspectives on youth and young adulthood, Journal of Sociology, 47(4):355-370.

Galland, O. (1996), Che cos'è la gioventù, in Cavalli e Galland (eds) Senza fretta di crescere. L’ingresso difficile nella vita adulta, Napoli: Liguori.

García Canclini, N (1989). Culturas hibridas. Estrategias para entrar y salir de la modernidad, Grijalbo, México

García Canclini, N. (1995) Consumidores y ciudadanos. Conflictos multiculturales de la globalización, Grijalbo, México, 1995 
García Canclini, N. 2006, Culturas urbanas de fin de siglo: la mirada antropológica, http://www.crim.unam.mx/cultura/ponencias/ponen2faseindice/Canclini.htm

Giddens, A. (1991) Modernity and Self-identity: Self and Society in the Late Modern Age. Stanford, CA: Stanford University Press.

Gilroy, P. (2002) There Ain't No Black in the Union Jack, London: Routledge.

Harris, A. (2002) Young Australian Women: Circumstances and Aspirations, Youth Studies Australia 21(4): 32-7.

Harris, A. (2004a) Jamming Girl Culture: Young Women and Consumer Citizenship in A. Harris (ed) All About the Girl. Culture, Power and Identity, London and New York: Routledge.

Harris, A. (2004b) Future Girl: Young Women in the Twenty-first Century, New York: Routledge.

Harris, A. (2009) Young people, politics and citizenship, in A. Furlong (ed) Handbook of Youth and Young Adulthood. New perspectives and agendas, London and New York: Routledge, 301-306.

Hebdige, D. (1979) Subculture: The Meaning of Style, London: Routledge.

Hesmondhalgh, D. (2005) Subcultures, scenes or tribes? None of the above, Jouurnal of Youth Studies, 8: 21-40.

Hillier, L. and Harrison, L. (2007) Building realities less limited than their own: young people practicing same-sex attraction on the internet, Sexualities, 10: 82-100.

Hodkinson, P. (2009) Spectacular youth? in A. Furlong (ed) Handbook of Youth and Young Adulthood. New perspectives and agendas, London and New York: Routledge, 276-282.

Holloway, S. L. and Valentine, G. (eds) (2000) Children's Geographies: Playing, Living, Learning, London: Routledge.

Jennings, M. and Stoker, L. (2004) Social trust and civic engagement across time and generations, Acta Politica, 39: 342-79. 
Klein, N. (2002) No Logo, New York: Picador.

Lasch, C. (1979) The Culture of Narcissism: American Life in an Age of Diminishing Expectations, New York: Norton.

Leccardi, C. (2005) Facing uncertainty: Temporality and biographies in the new century, Young, 13(2): 123-146.

Leccardi, C. (2009) Sociologie del tempo. Soggetti e tempo nella società dell'accelerazione. Roma-Bari, Laterza.

Leccardi, C. and M. Rampazi (1993) Past and Future in Young Women's Experience of Time, Time \& Society, 2(3) 353-379.

Levine, P. (2007) The Future of Democracy: Developing the Next Generation of American Citizens, Medford, MA: Tufts University Press.

Lincoln, S., (2012) Youth Culture and Private Space, Houndmills, Palgrave Macmillan.

Livingstone, S. (2006) Drawing conclusions from new media research: reflections and puzzles regarding children's experience of the internet, The Information Society, 22: 219-30.

Loader, B. (2007) (ed) Young Citizens in the Digital Age. Political Engagement, Young People and New Media, London and New York: Routledge.

Maffesoli, M. (1996) The Time of the Tribes: The Decline of Individualism in Mass Society, London: Sage.

McDonald, K. (1999) Struggle for Subjectivity: Identity, Action and Youth Experience, Cambridge: Cambridge University Press.

McRobbie, A. (1991) Feminism and Youth Culture: From Jackie to Just Seventeen, Boston: Unwin Hyman.

Modell, J., Furstenberg, Jr. and Hershberg, T. (1976) Social Change and Transitions to Adulthood in Historical Perspective, Journal of Family History, 1: 7-32.

Montgomery, K., Gottlieg-Robles, B. and Larson, G. O. (2004) Youth as e-citizens: Engaging the Digital Generation, Centre for Social Media, American University. 
Muggleton, D. (1997) The post-subculturalist. In: Redhead S, Wynne D, O’Connor J (eds) The Clubcultures Reader: Readings in popular cultural studies. Malden, MA: Blackwell, 167185.

Muggleton, D. (2000) Inside Subculture: The postmodern meaning of style. New York, NY: Berg.

Pieterse, J. N (1999): "Globalization as Hybridation" in Featherstone \& Lash (eds.) Spaces of culture: City, Nation, World, Sage, London.

Putnam, R. (1999) Bowling Alone: The Collapse and Revival of American Community, New York: Simon \& Schuster.

Richardson, W. (2006) Blogs, Wikis, Podcasts, Thousand Oaks, CA: Corwin Press.

Rosa, H. (2005) Beschleunigung. Frankfurt am Main, Suhrkamp.

Sánchez García, J. (2009). Juventud en sociedades árabes: ¿Cómo construyen su identidad? Un ejemplo etnográfico: El Cairo. http://www.tesisenxarxa.net/TDX-0610109115345/index.html\#documents

Sherrod, L., Flanagan C. A., Kassimir R. and Syversten A. B. (eds) (2005) Youth Activism: An international Encyclopedia, Westport, CT: Greenwood Publishing.

Stahl, G. (2003) Tastefully renovating subcultural theory: Making space for a new model, in D. Muggleton and R. Weinziert (eds) The Post-Subcultures Reader. New York, NY: 27-40.

Stokes, H., Wierenga, A. and Wyn, J. (2004) Preparing for the Future and Living Now, Melbourne: Youth Research Centre.

Threadgold, S. and P. Nilan (2009) Reflexivity of Contemporary Youth: Risk and Cultural Capital, Current Sociology 57(1): 47-68.

Thompson, J. (1995) The Media and Modernity: A Social Theory of the Media (Cambridge: Polity; Stanford: Stanford University Press.

Thornton, S. (1995) Club cultures: Music, media and subcultural capital. Cambridge: Polity. 
Vromen, A. (2003) People try to put us down...participatory citizenship of Generation X, Australian Journal of Political Science, 38 (1): 79-99.

Wyn, J and R. White (1997) Rethinking Youth. Sydney: Allen and Unwin.

Zeijl, E., Te Poel, Y., Du Bois-Reymond, M., Ravesloot, J. and Meulman, J. (2000) The role of parents and peers in the leisure activities of young adolescents, Journal of Leisure Research, 32: 281-301. 


\section{Contemporary studies on youth and youth cultures in South and East Mediterranean countries}

In the field of Middle Eastern Studies, the topic of youth cultures does not feature prominently among the studies of youth. Despite analysing young people's living conditions to a greater extent, social scientists have looked at youth as producer and consumer of specific cultures only during certain periods. Since the aftermath of the Arab Uprising (since late 2010 onwards), the academic community started to look into youth cultures in greater detail. This has notably been the case for young people's forms of artistic expression (for instance, rap music, street art and graffiti).

This survey of the existing literature aims to list the more relevant topics within the study of youth cultures in the Arab Mediterranean region, and also to originate some broader reflection on the issue of youth cultures and its contribution to the study of the Arab Mediterranean countries.

The literature review is organised as follows. Firstly, it reflects on the contribution that examinations of youth cultures can give to the study of youth in the Arab Mediterranean counties and, more broadly, to Middle Eastern Studies. Secondly, the survey moves on to cover and list the most relevant topics that the studies of youth have been engaging. Thirdly, it will look into the differences within this field of study. Finally, the survey provides a thematic reference list.

\subsection{The contribution of youth cultures to the study of youth in Arab Mediterranean countries}

Since the outbreak of the protests in late 2010, national and international media have turned their attention to 'Arab youth' and elected it as the protagonist of the uprisings. Unemployment, continuous dependence on foreign governments or international financial institutions (IFIs) ${ }^{23}$ for aid, betrayed life expectations, increasing obstacles to emigration towards Europe have been, according to observers and protagonists, the sparks of youth rage. Youth and youth living conditions then became a major issue in national as well as international politics (Marks 2013, Murphy 2012).

When it comes to Middle Eastern Studies and to the academic community, the relevance of youth as a social and political issue has been a surprise due to two main aspects. Firstly, contrary to what scholarship and studies on the Arab Mediterranean countries have pointed to in the last decades, political Islam has been a relatively marginal factor in the

\footnotetext{
${ }^{23}$ Notably, this is the case of Egypt that does rely on substantial funding from the US, but also of Morocco and Tunisia, which receive relevant financial support from the IMF, WB and the EU via development programs. On this, see Harrigan Jane, Wang Chengang and El-Said Hamed (2006), 'The econonomic and political demeterminants of IMF and WB lending in the MENA', World Development, Vol. 34, No. 2, pp. 247-270. On the post-uprisings era, see Adam Hanieh, (2015-forthcoming), 'Shifting Priorities or Business as Usual? IMF and WB Engagement with Tunisia, Morocco and Egypt' British Journal of Middle Eastern Studies, Vol. 42 , No. 1.
} 
revolts/revolutions. A significant number of studies indeed suggested that political Islam would have been the major oppositional force to authoritarian regimes in North Africa and beyond it (Roy 2008, Austin 2011). Despite this hypothesis being very popular, the revolutionary masses and young people have been displaying relatively few and marginal references to Islam as a militant religion, and the creation of an Islamic State or the application of the Sharia have not featured among the claims (Roy 2011 and 2012) ${ }^{24}$. The reference to Islam and religion indeed mainly related to social justice, and religious practices such as iftar or massive prayers featured among the repertoire of actions deployed during demonstrations. This happened not only in Egypt, where the Muslim Brotherhood joined the resistance in Tahrir Square only at a later stage, but also in Tunisia, Turkey and Morocco. This is relevant not only because evidence on the ground runs counter to the findings and hypothesis of the scholarship, but also because at the beginning of the revolts, Western media voices establishment fears of multiple 'Islamic republics' on the southern shore of the Mediterranean.

This misplaced expectation on political Islam also says a lot about Arab youth values, in particular that a change in youth values is taking place and that the values of the younger generation are to some extent different from the values of the previous generation. Therefore, it is of particular importance to focus on such a change and transformation of values, enlarging the focus to non-urban settings which should be contrasted with urban settings.

Nuancing the portray of Arab Mediterranean societies is of huge relevance, as the Arab countries have long been caught between contradictory totalising visions: authoritarian regimes constituting a progressive step in an evolution towards democracy - perceived as an exclusively 'Western' notion (the case of Tunisia and Morocco are good examples, both before and after the revolution) or countries doomed to succumb to radical Islamism.

Responding to such a dichotomic representations, "TheBigPharaoh@” a well-known avatar of Twitter started in 2012, writes on August 23 after the fall of Mursi: 'Dear Western media, if I am an anti-Islamist Egyptian, wear polo-shirts and hear Bon Jovi, that does not mean that I am liberal'. This exclamation remarks that in the five countries where the research is being carried out, Morocco, Egypt, Tunis, Algeria and Lebanon, globalization has an effect on young people but the significances are local. ${ }^{25}$ This also holds true for the claims and demands that protesters have voiced during the uprisings, which have been interpreted by observers through two dominant lenses. On the one side, some have enthusiastically seen in the uprising a demand for democracy, describing it as mainly lust for a 'Western'-template of liberal democracy (Stepan 2012, Hudson 2011). On the other side, some scholars have invalidated this representation by highlighting the relevance of demands for social justice instead of demands for liberal freedoms, and some have even echoed old Orientalists remarks

\footnotetext{
${ }^{24}$ This finding should be re-considered as an operational hypothesis during the project in order to reflect on the medium and long durée of the uprisings. Despite this being true in the aftermath of the uprisings, it might not be valid anymore in few years' time. Indeed it is accepted as conventional wisdom that the politics of the region, both in the short and in the long-term, has changed for good. This is potentially the case, but one should be aware that the complexity of earth-shattering events is considerable and that it takes time to tease out their impact, or that current dynamics might abruptly change. See Gilbert Achcar, The People Want (London: University of California Press, 2013).

${ }^{25}$ Quoted from Sanchez Garcia J., "Metal. Shabab-ologies: Researching Arab Mediterranean Youth", www.sahwa.eu, 29 August 2014.
} 
that democracy might not fit Arab societies. ${ }^{26}$ Despite demands for social justice being dominant, we should avoid narratives and representations that sharply depict 'Arab societies' as caught in totalising identities or demands. As highlighted by Youssef El-Chazli and Jasper Cooper (2012), taking part in a revolt as an individual is not necessary linked to a combination of well-defined political targets. Their ethnographic work in Tahrir Square shows how people signified their participation in the occupation during the action in itself. Thus, it is very important to dismantle such rigid representations by looking closely at values and changing youth cultures, with the goal of enriching our understanding of the cultural and political dynamic identities present in Arab Mediterranean societies and produced by the Arab youth.

The second reason why the visibility of Arab youth in the protest movements has surprised scholars is that the protagonists of the revolts were not those who scholars expected. Indeed, the scholarship on youth political engagement and participation has mainly focused on the socalled 'usual suspects' (Aarts and Cavatorta 2014), namely young people participating in secular or religious NGOs and charities, usually with a middle-class background ${ }^{27}$. The Uprisings highlighted the presence and political engagement of socially marginal constituencies (Beinin 2014), in particular young people coming from poor neighbourhoods (Sánchez García, 2011, 2013; Anceschi, Gervasio, Teti 2013). Despite the fact that Asef Bayat had already stressed poor people's movements and informal politics (Bayat 1997, 2013), the visibility of such marginal social groups has come as a sort of surprise for the scholarly community (Chomiak, 2011 and Chomiak and Entelis 2013; Beinin 2014). This suggests the necessity of bringing those seemingly 'non-political' social movements (neighbour peer groups, street vendors, street kids and football fan clubs, for instance) into the broader picture of youth political participation, in order to examine and get familiar with the culture and values they express. This seems to be of great relevance as scholars agree on the fact that Arab youth generally are quite distant from political parties, and they prefer individual action as a guarantor of political commitment, to more institutionalised forms of political commitment and participation. Young people appear in conflict with state nationalism and the expression of it, perceived as 'old'. Belonging to their time and society, their value and social references are no longer exclusively national, as they dream of other places, they are in search for dignity for themselves and for a meaning to their lives, to gain recognition face à the authoritarian system, as free individuals. ${ }^{28}$ Therefore, it is important to understand not only 'who' these young people are, but also 'what kind of values and culture' they express.

\subsection{The scholarship on youth in Arab Mediterranean countries}

In the broad scholarship on youth in the Arab Mediterranean countries, we find two distinctive major streams that mirror the same division we have in the study of youth at the

\footnotetext{
${ }^{26}$ For a discussion of dominant narratives about the 'Arab Spring', see Gilbert Achcar, The People Want (London: University of California Press, 2013).

${ }^{27}$ It is well-known and proved that middle-classes are a very relevant pool of support for Islamist parties and movement all across the Arab Mediterranean countries. See for instance Janine Clark 2004.

28 See Aissa Khadri, 'Locally rooted Youth and Social Movements in the Southern Mediterranean', in Intercultural trends and social change in the Euro-Mediterranean region, The Anna Lindh Report 2014, pp. 5356.
} 
international level: one focusing on the structural aspects of 'being young in the Middle East', the other focusing more specifically on the cultural aspects of being young in the Middle East. Before discussing these two broad fields in greater detail, this survey of the literature highlights a substantial difference between these two areas of literature when it comes to the theoretical refinement of studies and the number of them. It seems that those analyses focusing on the structural aspects are far greater in number and, generally speaking, scientifically more complex and complete. The study of youth cultures seems to suffer from the lack of theoretically strong analytical instruments applicable to the reality on the ground (such as, for instance, the concept of 'sub-culture' which is not widely used in the literature because it is regarded as not fit to capture the reality on the ground). Studies therefore result in being more descriptive than analytical and usually refer to broader issues discussed by political scientists, such as prospects for democratisation. Despite being 'live and kicking', youth cultures expressed for instance through ICTs, music, arts etc. seem not to warrant any complex or 'higher' theoretical reflection. However, some exceptions do exist, such as studies applying the concepts of 'urban tribe' and 'youth culture' to examine the Arab cultural scene. These studies mainly refer to urban settings. A working hypothesis for this research, then, could be refining conceptual tools to be applied to the case-studies considered, by reflecting for instance on the historical and social peculiarities that construct 'what youth is' as social category in the contexts under examination (Schielke, 2003, 2006, 2010; Sánchez García, 2009, 2010).

The first important characteristic of the scholarship on youth cultures in the Arab Mediterranean countries is the fact that scholars acknowledge a substantial shift in the social perception of 'youth' among Arab populations at large. Notably, youth has traditionally been perceived as a 'transitional period' from childhood to adulthood, which encompasses some 'transitional' rituals such as marriage. Nevertheless, scholars acknowledge that today youth is perceived to be a living condition per se, with youth in the Middle East struggling to exert their youthfulness in the present. Of course, preparing for life transitions in the future remains a challenge, in particular in a context of ubiquitous neoliberal reforms, authoritarian regimes, and ongoing regional conflicts with no resolution in sight. However, scholars focus on youth and youthfulness as such, and concentrate their scientific efforts on this particular 'subject' of study (Herrera 2011).

\subsubsection{Transition to adulthood}

The first area in the literature on youth in the Arab Mediterranean countries is the one focusing on the structural living conditions of young people. This literature is mainly sociological and quantitative, and looks at macro-economic data, surveys and statistics in order to build a working frame of reference for explaining the discontent and economic difficulties of young people in the region. Despite this holding true, there are interesting countertrends to consider.

According to statistic reported by the Anna Lindh Foundation (as reported in Tozy 2014), young people are generally confident in the future with $66 \%$ of the respondents self-defining in this way. It is reported that a difference of +12 points between the current and expected level of satisfaction among Arab Mediterranean youth is existent. European young adults are far more pessimistic than their Arab Mediterranean peers (22\% against 8\%). Possibly this 
difference is due to the effects of the economic and legitimacy crisis Europe and its institutions are going through, more than to those linked to Arab revolutions (Tozy 2014).

Nevertheless, the conditions of so many among the youth to make successful transitions from school to work and adulthood suggest a situation of widespread generational discontent. However, an opposite theme in the literature is also present, namely that the outgrowth of youth represents a potential opportunity, a 'demographic dividend' or 'demographic gift' (World Bank 2007; Egypt Human Development Report 2005; Wolfsensohn Center, Brookings Institution 2008; Ragui Assad and Farzaneh Roudi-Fahimi 2007; Hillary Silver 2007; See also the reference list). According to this reasoning, a large youthful population benefits national growth if human-capital policies develop them and turn them into potential sources of social and economic enrichment. However, shortcomings in the implementation of such policies and an approach to youth that privileges a neoliberal understanding of economic development through the youth does not adequately take into consideration issues of rights, equity, justice, citizenship, and aspirations of youth themselves. In other words, as noticed by Linda Herrera (2009), youth tend to be treated more as objects than as agents of social and political reform and economic development.

\subsubsection{Main trends and gaps in contemporary studies on youth cultures}

The second field of study present in the literature looks more specifically at youth cultures. This area focuses particularly on the use of ITC, and other forms of commodification of culture (rap music, shopping malls); on the religious expression of youth culture; and ambiguous forms of cultural productions and expressions (Schielke, 2008; Sánchez García, 2009). Here, studies on post-Islamism flourish (Roy 2012; Bayat 2002, 2005; See the reference list), even if more recently a great number of studies have been produced on the connection between more extreme and radical forms of Islamism (Salafism) and youth (Marks 2013; Merone and Cavatorta 2012; Haenni 2005, see also the reference list). In particular, within this second area, studies focus on a number of issues. The first issue is Post-Islamism, an expression forged by Olivier Roy and Asef Bayat (2004, 2005) which captures the value change in the new generation, and in particular their changed relationships with Islam. The concept of Post-Islamism identifies a shift in values in the younger generations, corresponding to a privatisation of faith. This does not mean that young people in the ME as secular, yet they are keener than their parents to wash away 'militantism' from religion. It is the refusal of a higher authority which, in the name of religion, imposes something on the people, more generally speaking, of 'narrow' religious and ideological identities, for young people show a tendency toward ideological 'bricolage' and hybrid forms of ideological commitment (Bayat 2005; Bayat and Herrera 2010; Beinin and Vairel 2013). In this sense, it is important to separate political Islam from religious practices and values that crosscut all social relations, as several authors had remarked. This distinction allows understanding the overlapping deployment by young people of graffiti or rap music as well as religious activities such as iftar, prayers or sufi practices (Sanchez García 2012). This 'new' way of understanding Islam also explains the proliferation of charismatic TV preachers (somehow inspired by a Protestant morality), who combine religious practice and social success as a sign of divine approval. Crucial influence is also exerted by transnational connections among Muslim communities residing in the region and outside of it. A good example is the Egyptian-Swiss intellectual Tariq Ramadan, who has a huge influence in the attempts at reforming Islamic thought. 
Transnational connections and influences should also be explored and further examined in the aftermath of the uprisings.

This new forms of Islamism and post-Islamist overlaps with traditional forms of religiosity performed by the Sufi brotherhoods and by rigorist or Salafist oriented-people, such as the Tabligh wa Dawa followers, who symbolise their religiosity through individual traditional representations as utilising traditional clothes and other body markers (Haenni and Holtrop, 2002).

The second aspect scholars have focused on is the broad issue of new media consumption in the Arab Mediterranean countries. ICT is indeed identified as the main factor highlighting generational differences and as an indicator of internal differences among young populations in the region. It is then an identity factor which distinguishes the younger generation as distinct from the previous (see reference list). Beyond public space, social networking also offers ways to a large part of the young population to affirm and express freedom of expression through a choice of styles, from subversive humour, to provocation, denunciation and self-reporting as new forms of expression, which are at odds with traditional communication. We find examples such as the 'Non-Fasters', 'Fataras' or 'Massayminch', who call for breaking the fast during the day in Morocco, Algeria, Tunisia, or the "public kiss' as a reaction to the prohibitions and fatwas of traditionalists and fundamentalists, or the emergence of new issues related to the private sphere of sexuality (i.e. the Facebook page 'ZAK' of the Algerian homosexual or virtual gay pride in the Maghreb, or the phenomenon of 'Harlem Shake' in Egypt and Tunisia).

These are also ways confirming the emergence of the individual hitherto standardised, excluded and grouped. These actions also mark the questioning of submission to authority as illustrated by the example of the young Amina in Tunisia. Under unstable circumstance, the 'civic pact' for the affirmation of youth and women as agents of change puts on top of the social struggles agenda those conditions that can give meaning to the requirements of freedom and participation: the status and role of the individual and his responsibility.

Given the persistence of authoritarianism in the Arab Mediterranean countries, scholars have been very reactive to the notion of 'looking for politics' in traditionally non-political environments or realms of activity. The lack of independent and autonomous political parties and trade unions, for instance, pushed scholars to turn their attention to Islamism (perceived to be the only genuine force of opposition to Arab authoritarian regimes, a view that generated significant shortcomings anyway, as mentioned earlier in this chapter) and to the so-called social non-movement. The latter is probably the most interesting and most novel field of inquiry, and represents the third aspect the studies have focused on. The concept of social non-movements suggests that mobilisation and dissent may originate from apparently 'non-political' contexts and groups. The scholarly attention on the sources of political mobilisation, then, should be enlarged from specifically and explicitly 'political actors' (Islamist opposition political parties, for instance), to other actors such as music-oriented gangs, neighborhoods' youth associations, sufi associations or football fans' clubs, as potential political actors. Studies have dealt with rap music, local hybrid music and the underground music scene (Sánchez García, 2010; Bostic 2011), football fans' clubs (Dorsey 2012; El Ghandour 2012; Tuastad 2013), street art (Demerdash 2012), informal politics (Sánchez García, 2013; Anceschi, Gervasio and Teti 2013) and (again) religious non- 
mainstream groups (Drisel 2007; Bekkaoui, Khalid, and Larémont 2011). In particular, football chanting among young football fans has attracted major attention (see James Dorsey's scholarship, in particular). The Internet has played a major role, as fans have found in the Internet social networks (YouTube, Facebook and Dailymotion) in particular as a new medium to (1) reframe their identity, in opposition to both the institutionalised discourse on youth and political legitimacy, and the imposed realities of geopolitics that constrain their mobility; (2) to express their malaise with the prevailing socio-economic conditions; and also (3) to construct their future 'imagined elsewhere' (Tuastad 2013). Major theoretical innovations revolve around the idea of the politicisation of what, previously, has wrongly been perceived to be a-political or non-political. When it comes to this specific issue, studies are still weak and are outnumbered by those focusing on NGOs activism and party membership. It is indeed of great relevance that scholars and researchers focus on apparently non-political activities in order to grasp very political and important dynamics related to urban spaces and self-management. This has to be done not solely for football fan clubs or rap singers. It has also to be done for religiously-inspired political activism. Studies on Salafism are flourishing, but are still a few and, theoretically speaking, there is room for making important contribution to the scholarship. Beyond Salafism, studies of TV preachers, for instance, could be completed. Such examinations would bridge media studies and cultural studies.

This third aspect connects to the fourth issue that Arab youth studies have focused on, namely youth and political participation. This last bulk of studies is distinct from the previous one as it has been built on the explicit question of why Arab young people have engaged in revolutionary politics despite the apathy they showed previously (Sika 2012). Furthermore, these studies have linked such re-ignited political activism to the structural conditions the Arab youth have to live in (prolonged unemployment, lack of opportunities, obstacles to migration, difficulty to make a successful transition to adulthood, lack of resources to make that transition and marry etc. See Al-Momani 2012, for instance; and reference list). In this context, youth cultures are also investigated as expressions of dissatisfaction with structural, living conditions (see also section above). Current themes in rap music and street art are claims for dignity, respect for rights (liberal rights but also material rights, such as the right to a respectable life), and condemnation of the previous regime's submission to Europe or to the US. These issues should be engaged more thoroughly by scholars, who should also turn to literature and narrative to grasp dynamics of cultural reproduction and consumption, two elements which might however be intertwined with political commitment. In terms of consumption an important issue is the relationship with Islam. Indeed, the traditional dichotomy between haram and halal orients consumption. 'Islamic' is a distinctive symbol in the market which reassures and warrants a legitimate consumption (Haenni, 2009).

As already mentioned earlier, the most relevant and dominant dynamic to be considered when it comes to youth and political participation in the Arab world is the prevalence of a noninstitutionalised (membership in political parties, official trade unions...) political engagement among the youth. As already mentioned, the overarching trend is towards a more individually-oriented and informal type of political participation - albeit not less relevant or effective. The scholarship has registered this major shift and described this trend to a great extent, as the uprisings have exposed this phenomenon very forcefully. This shift of modes of actions is also evidenced by value surveys, which highlight quite a relevant shift in values of youth. In particular, Mohamed Tozy (2014) and Sara Silvestri (2014) highlight how, 
according to the results of the survey they present, it emerges that when it comes to political participation the most important value is individual action, as opposite to collective action. Freedom is an important value, and $81 \%$ of the respondents defined it as a primary requirement in society. Silvestri, in particular, highlights the progressive reinforcement of secular values among the youth.

Following on from this, the so-called 'e-activism' and 'informal politics' have been examined in detail. When it comes to informal politics, some scholars have focused on the existing tension between informal politics as a clientelism-related phenomenon and as a trigger for the emergence of opposition social movements. Sánchez García has discussed how on the one hand, clientelism refers to a culture of deference, while on the other hand, informal politics seems to be closely linked to a culture of uprising and resistance. These informal solidarities are based on living in the same neighbourhood and on kinship and allows for the establishment of networks of reciprocity, obtaining the control of the neighbourhood yet to the advantage of the networks' members only (Sánchez García, 2013).

Another interesting area of research that should be further engaged deals with cosmopolitanism and the "claim of youthfulness". In particular, it would be of interest to look at how the recent waves of protests drawn cultural references from a cosmopolitan environment. This is something Adam K. Webb (2014) tried to examine by advancing the notion of "cosmopolitan traditionalism" meaning that pressures of globalisation and opportunities of democratic transition are forcing traditionalists on to more cosmopolitan terrain.

\subsubsection{Youth and internal diversity ${ }^{29}$}

Youth is not portrayed as a monolith, and internal differences are acknowledged. This is the case of gender, which is recognised and considered as one of the most relevant dimensions. In particular, the scholarship has made the point that the change in values (post-Islamic attitudes mentioned earlier) have impacted women in particular (Moghadam and Sadiqi 2006). However, the most recent literature points to novel direction of research, stemming from the turbulent times of the Uprisings and institutions-making in the aftermath of regime changes. Gender politics is acknowledged to be one of the most relevant dimensions of this postregime change institution-making. However, it has mainly been understood and discussed in ideological ways through the 'state feminist' discourses of the previous regimes as well as the governments that rose to power after the Arab Spring. Scholars acknowledge that female activism has shifted sharply away from a situation in which state-sanctioned women's associations were authorised to deal with the 'woman question' in North Africa and which were necessarily entangled with authoritarian governments. At same time, several scholars remarks the significance of local feminism deploying Islamic discourses and practices as an instrument to reduce gender inequalities. The collapse of those political systems however liberated more room for non-institutional activism and feminism on the streets and through cyber-space on Facebook, Twitter and blogging. These dynamics have de-centralised gender activism (Singerman 2014; Le Renard 2014; Khalil 2014), and deserve further attention.

\footnotetext{
${ }^{29}$ We deploy the term 'diversity' instead of 'difference' because it is widely used in the scholarship.
} 
In the context of the Arab Spring, popular pressures have been applied to the new governments by a wide range of groups of women whose opinions are redefining how constitutional and legal language treats gender in newly debated definitions of national identity. This shift in the women's rights question from state-defined action to atomised forms of cyber activism and street action is characteristic of the broader shifts in North African popular politics that culminated in the Arab Spring. This is in line with the finding from the study of activism, informal politics and social non-movement as inherently political, despite their apparently non-political characteristics (see point 3 in previous section). Politics is no longer controlled by a single party, set of state actors or a by a single man. Rather, it has increasingly taken the form of popular 'activisms', rejecting state-imposed binaries such as state/society in favour of non-institutional forms of political intervention and contestation. The call for gender dignity and justice, in this new period, echoes the style, media and dynamics of Arab Spring politics more broadly. Despite being recognised by the scholar, these dynamics of autonomy of activism and feminist activism in particular deserve further examination. In particular, it could be analysed how dynamics of economic disempowerment caused by structural conditions have impacted on women, and how did it happen that those women took part in the protests. Female informal workers or poor women could indeed offer a privileged point of observation for wider dynamics of political empowerment.

Another internal difference is the religious one, although there has not been much attention placed on changing values among religious minorities in Arab Mediterranean countries, neither on what culture their young people may produce nor consume. This is probably due to the over-emphasis on the supposedly anti-democratic nature of Muslim peoples. This emphasis has had a huge impact on the study of Arab Mediterranean countries, with almost all scholars engaged in dismantling Orientalism, neo-Orientalism and its claims. In this field, there is a well-established tradition of survey examination and value analysis, which produced milestones and crucial studies in dismantling Orientalist assumptions about 'Muslim' values (see Tessler \& Jamal's scholarship - reference list). This is probably the reason why minorities (Christian minorities) are understudied, so that Orientalist assumptions about the link between religion and values might not gain further ground. Existing studies are mainly based on surveys and point out the general appreciation of diversity, whereby youth in Arab Mediterranean countries believes a little more in the benefits of diversity for public debate compared to adults ( +5 points in Arab Mediterranean and +1 in Europe) (Tozy 2014).

However, more specific attention and research engagement with this issue could be of interest because after the uprisings, the protection of religious minorities' rights has become a relevant issue in the public debate, both domestically and internationally. So far, scholars have been looking at formal constitution-writing to assess whether minority's rights were protected or not, and have linked the positive predisposition to protect them to democracy (Stepan 2012; El-Issawi 2011). Studies focusing on the cultural production of young people from religious minorities in the Arab Mediterranean region are so far scarce and therefore, engaging the topic of minorities' youth culture would be of great relevance and innovation. Studies are scarce alike when it comes to ethnic minorities, except for peculiar contexts such as Lebanon and Israel/Palestine. In the case of Lebanon, the focus is on religion as a mean to express ethnic belonging (Harb and Deeb 2013), whereas in the case of Israel/Palestine there is a consistent literature on 'underground' cultural and political form of expression (notably, rap music and street art). 
When it comes to social class, the debate first revolves around the question of the existence of social classes in Arab Mediterranean countries, because of the absence of an industrial revolution, because of the relative size of the 'working class' and because social classes have been defined over the time in the Arab Mediterranean countries according to other criteria than property, such as the possession of culture and knowledge (Armbrust 2000, 2002). However, the prominence of trade-unionism in the uprisings and the crucial role of workers' mobilisations both in Tunisia and Egypt (Amin Allal 2010; Beinin and Vairel 2013) have reignited scholars' attention to class politics and workers' movement. Beyond this, class politics has also been connected to the emergence of Salafim in North Africa, a more radical version of Islamism, itself internally diversified, which is to some extents at odds with the mainstream Islamism of Ennahda in Tunisia and the Muslim Brotherhood in Egypt (see Wolf 2013; Marks 2013; Merone and Cavatorta 2012; Merone 2015; for a discussion about the problematic nature of the moderate/radial divide and 'labelling' of Islamism, see Schwedler 2015). Although with no agreement and internal discussion (Lacroix 2004; Clark 2004), scholars generally link the condition of being disinherited and deprived to being inclined toward radicalism and Salafism because this condition would favor the anti-system proposal (Merone and Cavatorta 2012) that Salafists advance.

\subsubsection{Thematic reference list}

Youth in the MENA: A focus on the economic and social structure

\section{- Examining the constraints to transitioning to adulthood}

Silver, H. (2007). Social exclusion: comparative analysis of Europe and Middle East Youth. Middle East Youth Initiative Working Paper, (1).

Singerman, Diane. "The economic imperatives of marriage: emerging practices and identities among youth in the Middle East." Middle East Youth Initiative Working Paper 6 (2007)

Assaad, Ragui, and Farzaneh Roudi-Fahimi. Youth in the Middle East and North Africa: demographic opportunity or challenge?. Washington, DC: Population Reference Bureau, 2007.

Salehi-Isfahani, Djavad, and Navtej Dhillon. "Stalled youth transitions in the Middle East: A framework for policy reform." Middle East Youth Initiative Working Paper 8 (2008).

Chaaban, Jad. "The costs of youth exclusion in the Middle East." Middle East Youth Initiative Working Paper 7 (2008).

Assad, Ragui, and Ghada Barsoum. "Youth Exclusion in Egypt: In Search of'Second Chances'." Middle East Youth Initiative Working Paper 2 (2007).

Roudi, Farzaneh. "Youth Population and Employment in the Middle East and North Africa: Opportunity or Challenge?." Population Reference Bureau (2011). 
Roudi-Fahimi, Farzaneh, and Shereen El Feki. "Facts of life: youth sexuality and reproductive health in the Middle East and North Africa." (2011).

Binzel, Christine. Decline in social mobility: Unfulfilled aspirations among Egypt's educated youth. No. 6139. Discussion Paper series, Forschungsinstitut zur Zukunft der Arbeit, 2011. (http://www.econstor.eu/bitstream/10419/58500/1/690186584.pdf)

El-Ghalia, Hana A. "Higher Education and Youth Unemployment in Lebanon." Comparative and International Higher Education 2.1 (2010): 12-13.

Haouas, IIham, Edward Sayre, and Mahmoud Yagoubi. "Youth unemployment in Tunisia: Characteristics and policy responses." (2012).

Assaad, Ragui. "Unemployment and Youth Insertion in the Labour market in Egypt." HK Eddin, The Egyptian Economy: Current Challenges and Future Prospects (2008): 133-178.

World Bank, World Development Report 2007: Development and the Next Generation, (Washington, D.C.: World Bank Publications, 2007).

Egypt Human Development Report 2005: Choosing our Future: Towards a New Social Contract (Cairo: UNDP and Institute of National Planning, 2005.

Wolfsensohn Center, Brookings Institution, From Oil Boom to Youth Boon: Tapping the Middle East Demographic Gift, conference proceedings, 7 January 2008, http://www.brookings.edu/ /media/Files/events/2008/0107 youth/20080107 youth.pdf (accessed 15 April 2008).

Armbrust. W. 2000. Mass Culture and Modernism in Egypt. Cambridge University Press.

Armbrust, W. 2002. "The riddle of Ramadan: media, consumer culture, and the 'Christmatization' of a Muslim Holiday" en Bowen, D. y Early. E. (eds.) Everyday life in the Middle East. pp. 335-348, Indiana University Press, Blomington

Bayat, A. 2000 "Who is afraid of Ashwaiyyat? Urban Change and Politics in Egypt. Enviroment and Urbanization, $\mathrm{n}^{\circ} 12$, International Institute for Environment and Devolopment, Sage Publications, pp. 185-199, London.

Bennani-Chraïbi, M y Farag, I. (eds.) 2007. Jeunesse des sociétés arabes: par-delà les menaces et les promesses, CEDEJ/Aux Lieux d'Etre, El Cairo/Mountreil.

\section{- Examining democratization prospects, activism, religious radicalism}

Beinin Joel, Civil Society, NGOs, and Egypt's 2011 Popular Uprising, South Atlantic Quarterly, Vol. 133, No. 2, 2014, pp. 396-403.

El Chazli, Youssef and Jasper Cooper, On the Road to Revolution. How Did "Depoliticized" Egyptians Become Revolutionaries?, Revue française de science politique, Vol. 62, No. 5, 2012, pp. 79-101. 
Paul Aarts and Francesco Cavatorta, eds., Civil Society in Syria and Iran: Activism in Authoritarian Contexts, Lynne Rienner 2014. Introduction, pp. 1-17

Stepan, Alfred C. 'Religion, democracy, and the" Twin Tolerations', Journal of Democracy 11.4 (2012): 37-57.

Schwedler, Jillian, Why academics can't get beyond moderates and radicals, Washington Post, $12 \quad$ February $2015 \quad$ (http://www.washingtonpost.com/blogs/monkeycage/wp/2015/02/12/why-academics-cant-get-beyond-moderates-and-radicals/).

Hudson M., 'Awakening, Cataclysm, or just a Series of Events? Reflections on the Current Wave of Protest in the Arab World', Jadaliyya 2011, Blog, May 16. Available at: http://www.jadaliyya.com/pages/index/1601/awakening-cataclysm-or-just-a-series-of-eventsref

Merone, Fabio, and Francesco Cavatorta. "The emergence of Salafism in Tunisia." Retrieved September 10 (2012): 2012.

Al-Momani, Mohammad. "The Arab "Youth Quake": Implications on Democratization and Stability." Middle East Law and Governance 3.1-2 (2011): 1-2.

Austin, Leila. "The Politics of Youth Bulge: From Islamic Activism to Democratic Reform in the Middle East and North Africa." SAIS Review 31.2 (2011): 81-96.

Clark, Janine A. Islam, charity, and activism: Middle-class networks and social welfare in Egypt, Jordan, and Yemen. Indiana University Press, 2004.

Lacroix Stéphane, 'Between Islamists and Liberals: Saudi Arabia's "new" Islamic-liberal reformists', The Middle East Journal, Vol. 58, No. 3, pp. 345-365.

Knickmeyer, Ellen. "The Arab world’s youth army." Foreign Policy 27 (2011).

LaGraffe, Dan. "The Youth Bulge in Egypt: An Intersection of Demographics, Security, and the Arab Spring." Journal of Strategic Security 5.2 (2012).

Staeheli, Lynn, and Caroline R. Nagel. "Whose awakening is it? Youth and the geopolitics of civic engagement in the "Arab Awakening'." European Urban and Regional Studies 20.1 (2013): 115-119.

Ibrahim, Barbara Lethem, and Leah Hunt-Hendrix. Youth, Service and Pathways to Democracy in Egypt. American University in Cairo, John D. Gerhart Center for Philanthropy and Civic Engagement, 2011.

(http://www.aucegypt.edu/research/gerhart/Documents/Youth\%20and\%20Democracy\%20wo rking\%20paper\%20Cover.pdf)

Murphy, Emma C. "Problematizing Arab youth: generational narratives of systemic failure." Mediterranean Politics 17.1 (2012): 5-22. 
Joksic, Mladen, and Marlene Spoerri. "From resistance to revolution and back again: What Egyptian youth can learn from Otpor when its activists leave Tahrir Square." Carnegie Council for Ethics in International Affairs Report 18 (2011).

(http://www.carnegiecouncil.org/publications/articles_papers_reports/0087.html/_res/id=sa_F ile1/JoksicSperri_Otpor.pdf)

Shehata, Dina. "Youth Activism in Egypt." Arab Reform Brief 23 (2008).

Sika, Nadine. "Youth Political Engagement in Egypt: From Abstention to Uprising." British Journal of Middle Eastern Studies 39.2 (2012): 181-199.

Singerman, Diane. "Youth, Gender, and Dignity in the Egyptian Uprising." Journal of Middle East Women's Studies 9.3 (2013): 1-27.

Sparre, Sara Lei. Muslim youth organisations in Egypt: actors of reform and development? DIIS, 2007.

(http://dcism.dk/graphics/Publications/Briefs2008/scj_Muslim\%20youth\%20organisations\%2 0in\%20Egypt.pdf)

Special issue, Mediterranean Politics Vol. 17 No. 1, 2012, Arab Youth \& Politics.

Roy, Olivier. "Al Qaeda in the West as a Youth Movement: The Power of Narrative. CEPS Policy Briefs No. 168, 28 August 2008." (2008): 8.

Roy Olivier, "This is not an Islamic revolution", The New Statesman, 3 February (http://www.newstatesman.com/religion/2011/02/egypt-arab-tunisia-islamic)

Roy, Olivier. "The transformation of the Arab world." Journal of Democracy 23.3 (2012): 518.

Bayat, Asef. "Activism and social development in the Middle East." International Journal of Middle East Studies 34.01 (2002): 1-28.

Bayat, Asef. "What is post-islamism?" ISIM Review 16 (2005): 1.

Anceschi, Luca, Gennaro Gervasio, and Andrea Teti, eds. Informal Power in the Greater Middle East: Hidden Geographies. Routledge, 2014.

Chaaban, Jad. "Youth and development in the Arab countries: The need for a different approach." Middle Eastern Studies 45.1 (2009): 33-55.

Austin, Leila. "The Politics of Youth Bulge: From Islamic Activism to Democratic Reform in the Middle East and North Africa." SAIS Review 31.2 (2011): 81-96.

Allal, Amin. "Réformes néolibérales, clientélismes et protestations en situation autoritaire." Politique africaine 1 (2010): 107-125.

Beinin, Joel, and Frédéric Vairel, eds. Social movements, mobilization, and contestation in the Middle East and North Africa. Stanford University Press, 2013. 
Wolf, Anne. "An Islamist 'renaissance'? Religion and politics in post-revolutionary Tunisia." The Journal of North African Studies 18.4 (2013): 560-573.

Webb, Adam K. "The rise of the cosmopolitan traditionalists: From the Arab Spring to a global countermovement?." International Political Science Review (2014) On line first (http://ips.sagepub.com/content/early/2014/04/17/0192512113516901.full.pdf+html)

Haenni, P. and Holtrop, T. 2002. "Mondaines spiritualités. Amr Khalid, shaykh branché de la jeunesse dorée du Caire”, Politique africaine, n 87, Paris 2002 pp. 45-68.

Haenni, P. 2005. L'ordre des caïds. Conjurer la dissidence urbaine au Caire, CEDEJ, Khartala, Paris

Haennni, P. 2009. "The Economic Politics of Muslim Consumption” en Pink, J. (eds) Muslim societies in the Age of Mass Consumption: Politics, Culture and Identity between the local and the global, Cambridge Scholars Publishing, Cambridge.

\section{Youth in the MENA: A focus on culture and subjectivities}

Ted Swedenburg, Imagined Youths, MERIP 245 (www.merip.org/mer/mer245/imaginedyouths)

Jung, Dietrich, Marie Juul Petersen, and Sara Lei Sparre. Politics of Modern Muslim Subjectivities: Islam, Youth, and Social Activism in the Middle East. Palgrave Macmillan, 2014.

Herrera, Linda. "Pensée 1: Youth and Generational Renewal in the Middle East." International Journal of Middle East Studies 41.03 (2009): 368-371.

Adely, Fida. "Pensee 2: Everyday Youth Places: Youth in Educational Spaces." International Journal of Middle East Studies 41.03 (2009): 372-373.

Bayat, Asef. Life as politics: How ordinary people change the Middle East. Stanford University Press, 2013.

(https://openaccess.leidenuniv.nl/bitstream/handle/1887/15229/A.+Bayat+-

+ Life+as+Politics.pdf? sequence $=1$ )

Bayat, Asef. Street politics: poor people's movements in Iran. Columbia University Press, 1997.

Chomiak, Laryssa, and John P. Entelis. "The Making of North Africa's Intifadas." Middle East Report 259 (2011): 8-15.

Chomiak, Laryssa. "Making of a Revolution in Tunisia, The." Middle EL \& Governance 3 (2011): 68 . 
Chomiak, Laryssa. "Confronting Authoritarianism: Order, Dissent, and Everyday Politics in Modern Tunisia." (2011).

Chomiak, Laryssa, and John P. Entelis. "5 Contesting order in Tunisia." Civil Society Activism Under Authoritarian Rule: A Comparative Perspective (2012): 73.

Special issue, Journal of Middle East Women's Studies, Vol. 9, No. 3, 2013: Youth, Gender, and Dignity in the Egyptian Uprising

Special issue, The Journal of North African Studies, Vol. 19, No. 2, 2014: Women, Gender and the Arab Spring

el-Issawi, Fatima. "The Arab Spring and the challenge of minority rights: will the Arab revolutions overcome the legacy of the past?." European View 10.2 (2011): 249-258.

Bayat, Asef, and Linda Herrera, eds. Being young and Muslim: new cultural politics in the global south and north. Oxford University Press, 2010.

Haeri, N. 2003. Sacred Language, Ordinary People: Dilemmas of Culture and Politics in Egypt. Palgrave MacMillan.

Mahmood, S. 2001. "Feminist Theory, Embodiment, and the Docile Agent: Some Reflections on the Egyptian Islamic Revival", Cultural Anthropology, Vol. 16, n² 2, pp. 202-236

\section{- Culture(s)}

Abaza, Mona. "Shopping malls, consumer culture and the reshaping of public space in Egypt." Theory, Culture \& Society 18.5 (2001): 97-122.

Bostic, Karl. "How rap music fueled the Arab Spring uprisings." NBC, September 15 (2011). Dorsey, James M. "Pitched Battles: The Role of Ultra Soccer Fans in the Arab Spring." Mobilization: An International Quarterly 17.4 (2012): 411-418.

El Ghandour, Taghreed. "How Football are reshaping Arab Spring Countries' Politics and Culture: Egypt's Ultras as a Case Study." (2012).

Demerdash, Nancy. "Consuming Revolution: Ethics, Art, and Ambivalence in the Arab Spring." New Middle Eastern Studies 2 (2012).

Tuastad, Dag. "From football riot to revolution. The political role of football in the Arab world." Soccer \& Society ahead-of-print (2013): 1-13.

Marks, Monica. "Youth Politics and Tunisian Salafism: Understanding the Jihadi Current." Mediterranean Politics 18.1 (2013): 104-111.

Bayat, Asef. "Piety, privilege and Egyptian youth." Isim Newsletter 10 (2002): 1.

Harik, Judith P. "Perceptions of Community and State among Lebanon's Druze Youth." The Middle East Journal (1993): 41-62. 
Wheeler, Deborah L. "The Internet and youth subculture in Kuwait." Journal of Computer-Mediated Communication 8.2 (2003): 0-0.

Dialmy, Abdessamad. "Moroccan youth, sex and Islam." Middle East Report 28 (1998): 1617.

Deniz Kandiyoti (ed), Fragments of Culture: The Everyday of Modern Turkey, 2011, IB Tauris

Drissel, David. "Online Jihadism for the Hip-Hop Generation: Mobilizing Diasporic Muslim Youth in Cyberspace." The International Journal of Interdisciplinary Social Sciences 2.4 (2007): 7-20.

El-Khairy, Omar. "'Freedom's a Lifestyle Choice': US Cultural Diplomacy, Empire's Soundtrack, and Middle Eastern'Youth'in our Contemporary Global Infowar." Middle East Journal of Culture and Communication 2.1 (2009): 115-135.

Bekkaoui, Khalid, and Ricardo René Larémont. "Moroccan Youth Go Sufi." The Journal of the Middle East and Africa 2.1 (2011): 31-46.

Khemissi, Hamidi, Ricardo René Larémont, and Taybi Taj Eddine. "Sufism, Salafism and state policy towards religion in Algeria: a survey of Algerian youth." The Journal of North African Studies 17.3 (2012): 547-558.

Bekkaoui, Khalid, Ricardo René Larémont, and Sadik Rddad. "Survey on Moroccan Youth: Perception and Participation in Sufi Orders/Evaluation and Interpretation." The Journal of the Middle East and Africa 2.1 (2011): 47-63.

Schielke, Samuli. 2003. "Habitus of the authentic, order of the rational: contesting saints' festivals in contemporary Egypt" Middle East Critique, 12(2): 155 - 172.

Schielke, Samuli 2006. Snacks and Saints: Mawlid Festivals and the Politics of Festivity, Piety and Modernity in Contemporary Egypt. PhD thesis, University of Amsterdam, Faculty of Social and Behavioural Sciences, PDF document.

Schielke, S. 2009a. "Being good in Ramadan: ambivalences, fragmentation, and the moral self in the lives of young egyptians" Journal of the Royal Anthropological Institute, N. S. pp. 24-40, Londres

Schielke, S. 2009b. "Ambivalent Commitments: Troubles of Morality, Religiosity and Aspiratin among Young Egiptians" Journal of Religion in Africa, $\mathrm{n}^{\circ}$ 39, pp. 158-185 Brill, Leyden.

Sims, David, El-Shorbagi, Muhamada y Séjoumé, Mahmoud. 2003. Understanding Slums: Case Studies for the Global Report on Human Settlements. The Case of Cairo, Egypt, on line at: www.ucl.ac.uk/dpuprojects/ 
LeVine, Mark. "Heavy metal Muslims: the rise of a post-Islamist public sphere." Contemporary Islam 2.3 (2008): 229-249.

Popular Music, special issue, Middle East Issue Vol. 15, No. 3, Oct., 1996

Sánchez García, J. 2014 "From 'Hara' to 'Midam': Urban Politic Spaces of Youth in Cairo" en Carles Feixa, Carmen Leccardi and Palm Nilam (eds.) Spaces and Times of Youth Cultures in the Global City Ed. The Hague and New York: Brill (in press)

Sánchez García, J. 2013 "Tahrir and the Rejection Culture: Countercultures and Revolution in Egypt" in Feixa, C. Nofre, J. (eds.) The Angry Generation: Topias and utopias of $15 \mathrm{M}$ and beyond. Ed. Mediterranea. Lleida (Octubre 2012).

Sánchez García, J. "Society against the Egyptian State: Ethno-historic Perspectives of an Unfinished Revolution" Quaderns I. C. A. Anthropological Catalonian Institute 23. 2012

Sánchez García, J. "Youth in Revolutionary times: Political Protagonism and youth agency in the riots of North Africa" in Alvarez (eds.) Civil Society in Middle East. Ed. Bellatera, Barcelona- 2011

Sánchez García, J. "Fort Squares: From Midam Tahrir to Catalonian Square: Public space and contemporary popular riots" in Urban Crespo (Coord.) Occupy the World! Ed. Icaria, Barcelona

Sánchez García, J. "Between modernity and tradition: Forms to be young in Cairo" Quaderns I. C. A. Anthropological Catalonian Institute 16. 2011

Sánchez García, J. "Youths from Other Worlds. Urban Tribes or Youth culture? Contributions from No Western Contexts" Revista Cuadernos de Antropología Social. Instituto de Ciencias Antropológicas. Universidad de Buenos Aires, Buenos Aires. 2010

Sánchez García, J. 2010. "From saints celebrations to Mulid Dance Music: utopy, identity and youth in Egypt". Trans: Revista transcultural de Música 2009. On line. ISSN:1697-0101.

\section{- Values}

Tozy Mohammed, 'In search of the Mediterranean core values', in Intercultural trends and social change in the Euro-Mediterranean region, The Anna Lindht Report 2014, pp.27-34.

Silvestri Sara, 'Religious and social cohesion at the heart of the intercultural debate', in Intercultural trends and social change in the Euro-Mediterranean region, The Anna Lindht Report 2014, pp.

Jamal, Amaney A., and Mark A. Tessler. "Attitudes in the Arab world." Journal of Democracy 19.1 (2008): 97-110.

Jamal, Amaney, and Irfan Nooruddin. "The democratic utility of trust: A cross-national analysis." The Journal of Politics 72.01 (2010): 45-59. 
Jamal, Amaney. "Civil liberties and the otherization of Arab and Muslim Americans." Race and Arab Americans Before and After 9/11: From Invisible Citizens to Visible Subjects (2008): 114-130.

Tessler, Mark, and Amaney Jamal. "Political attitude research in the Arab world: Emerging opportunities." PS: Political Science \& Politics 39.03 (2006): 433-437.

Jamal, Amaney. "Reassessing Support for Islam and Democracy in the Arab World?." Annual Meeting of the American Association of Political Scientists. 2005.

Tessler, Mark. "Do Islamic orientations influence attitudes toward democracy in the Arab world? Evidence from Egypt, Jordan, Morocco, and Algeria." International Journal of Comparative Sociology 43.3-5 (2002): 229-249.

Hegasy, Sonja. "Young authority: quantitative and qualitative insights into youth, youth culture, and state power in contemporary Morocco." The Journal of North African Studies 12.1 (2007): 19-36.

Moghadam, Valentine M., and Fatima Sadiqi. "Women's Activism and the Public Sphere: An Introduction and Overview." JMEWS 2.2 (2006): 1-7.

Kucinskas, Jaime. "A research note on Islam and gender egalitarianism: An examination of Egyptian and Saudi Arabian youth attitudes." Journal for the Scientific Study of Religion 49.4 (2010): 761-770.

Çileli, Meral. "Change in value orientations of Turkish youth from 1989 to 1995." The Journal of Psychology 134.3 (2000): 297-305.

Saktanber, Ayşe. "We Pray Like You Have Fun': New Islamic Youth in Turkey between Intellectualism and Popular Culture." Fragments of culture: The everyday of modern Turkey (2002): 254-76.

Davis, Susan S., and Douglas A. Davis. "'The mosque and the satellite": Media and adolescence in a Moroccan town." Journal of Youth and Adolescence 24.5 (1995): 577-593.

Shahine, Selim H. "Youth and the revolution in Egypt (Respond to this article at http://www. therai. org. uk/at/debate)." Anthropology today 27.2 (2011): 1-3.

Sparre, Sara Lei, and Marie Juul Petersen. "Youth \& social Change in Jordan \& Egypt." ISIM Review 20 (2007): 2.

Hegasy, Sonja. "Empirical Youth Studies in the Arab World." ORIENT-HAMBURG-. (2004): 179-184.

Johnston, Sholeh. "Persian Rap: The Voice of Modern Iran's Youth." Journal of Persianate Studies 1.1 (2008): 102-119. 
Saktanber, Ayşe. "Cultural Dilemmas of Muslim Youth: Negotiating Muslim Identities and Being Young in Turkey" Turkish Studies 8.3 (2007): 417-434.

Deeb, Lara, and Mona Harb. "Choosing Both Faith and Fun: Youth Negotiations of Moral Norms in South Beirut." Ethnos 78.1 (2013): 1-22.

Onodera, Henri. "" Raise Your Head High, You're An Egyptian!" Youth, Politics, and Citizen Journalism in Egypt." Sociologica 3 (2011): 0-0.

Asmar, Christine, Maroun Kisirwani, and Robert Springborg. "Clash of politics or civilizations? Sectarianism among youth in Lebanon." Arab studies quarterly (1999): 35-64.

Rad, Anahita Motazed. "Youth Role in the Arab Spring." Journalism and Mass Communication 2.6 (2012): 691-700.

Mensch, B., Ibrahim, B., Lee, S. and El-Gibaly, O. 2003. "Gender-Role Attitudes among Egyptian Adolescents" Studies in Family Planning, Vol. 34, No 1, pp. 8-18.

\section{- New social media (ICT)}

Kraidy, Marwan M., and Joe F. Khalil. "Youth, media and culture in the Arab world." International Handbook of Children, Media and Culture. Sage, London (2008): 336-350.

Lynch, Marc. The Arab uprising: The unfinished revolutions of the new Middle East. PublicAffairs, 2013.

Harmon, Mark. "Arab Youth, TV Viewing \& "Affluenza"." Arab Media and Society 6.Fall (2008): 1-6.

Herrera, Linda. "Youth and citizenship in the digital age: A view from Egypt." Harvard Educational Review 82.3 (2012): 333-352.

Ghannam, Jeffrey. "Social Media in the Arab World: Leading up to the Uprisings of 2011." Center for International Media Assistance 3 (2011).

Stepanova, Ekaterina. "The role of information communication technologies in the "arab spring"." Implications beyond the Region. Washington, DC: George Washington University (PONARS Eurasia Policy Memo no. 159 (2011).

Tufekci, Zeynep, and Christopher Wilson. "Social media and the decision to participate in political protest: Observations from Tahrir Square." Journal of Communication 62.2 (2012): 363-379.

Eltantawy, Nahed, and Julie B. Wiest. "The Arab Spring| Social Media in the Egyptian Revolution: Reconsidering Resource Mobilization Theory." International Journal of Communication 5 (2011): 18. 
Ghareeb, Edmund. "New media and the information revolution in the Arab world: An assessment." The Middle East Journal (2000): 395-418.

Lynch, Marc. Voices of the new Arab public: Iraq, Al-Jazeera, and Middle East politics today. Columbia University Press, 2006.

Khondker, Habibul Haque. "Role of the new media in the Arab Spring." Globalizations 8.5 (2011): 675-679.

Gerbaudo, Paolo. Tweets and the streets: social media and contemporary activism. Pluto Press, 2012.

Lim, Merlyna. "Clicks, cabs, and coffee houses: Social media and oppositional movements in Egypt, 2004-2011." Journal of Communication 62.2 (2012): 231-248.

Ginsburg, Faye D., Lila Abu-Lughod, and Brian Larkin, eds. Media worlds: Anthropology on new terrain. Univ of California Press, 2002.

Eickelman, Dale F., and Jon W. Anderson. New media in the Muslim world: The emerging public sphere 2 (2003).

Armbrust, Walter, ed. Mass mediations: New approaches to popular culture in the Middle East and beyond. Univ of California Press, 2000.

Lotan, Gilad, et al. "The Arab Spring| the revolutions were tweeted: Information flows during the 2011 Tunisian and Egyptian revolutions." International Journal of Communication 5 (2011): 31 .

Sreberny, Annabelle. "Mediated culture in the Middle East: Diffusion, democracy, difficulties." International Communication Gazette 63.2-3 (2001): 101-119. 


\section{PART 2. RESEARCHING YOUTH CULTURES IN THE SAHWA PROJECT}

\section{Research questions}

This chapter outlines some key analytical directions that should be explored, in order to apply the conceptual framework articulated so far in the paper to the main objectives of the Working Package 4 "Youth cultures: values, representations and social conditions".

As we explained in the introduction, this thematic Work Package rests on the conception of young men and women as active agents who contribute to the production, reproduction and transformation of the cultural values, norms and meanings of the society they inhabit. It encompasses a special focus on the contemporary dynamics of cultural production and consumption involving young people and, more broadly, on their cultural and symbolic activities. It aims at understanding how different young people, in different contexts, negotiate, give meaning to and handle the constraints and opportunities linked to their structural position. It focuses on the change in values, subjectivities and forms of cultural expression of young men and women in Arab Mediterranean countries. Last but not least, this thematic Work Package pays special attention to the key issue of difference. It aims to identify and describe how differences related to gender, class, ethnicity, religion and sexual orientation make youth cultural expressions in Arab Mediterranean countries plural, heterogeneous and worthy of being analysed through a complex and intersectional view.

The analysis of the literature on youth and youth cultures in Western contexts and Arab Mediterranean countries seems to indicate the emergence of common (or even convergent) dynamics in youth condition, which we suggest to explore further in our research project.

Our analysis reveals the crucial role of youth agency in dealing with the growing uncertainty that characterizes the complex, and globally interconnected, contemporary societies. There are evidences of common trends of prolongation, fragmentation and individualization of the process of transition to adulthood in Western contexts as well as in Arab Mediterranean countries, beyond the local specificities and the relevant social, geographical and cultural differences. ${ }^{30}$ These evidences suggest the hypothesis of a convergence of the structural and political $^{31}$ elements which frame the contemporary transformation of youth, which is increasingly defined as a condition marked by specific cultural expressions and subjectivities, rather than a mere transitional stage of life. A common ground for the living experiences of

\footnotetext{
${ }^{30}$ Please refer to page 24 for an overview of these issues.

${ }^{31}$ Political scientists also have highlighted a convergence of policies and modes of government between the political regimes on the Northern and Southern shores of the Mediterranean. They have used expression such as 'convergence of governance' and 'convergent (il) liberalism in the Mediterranean' to point out this phenomenon. This phenomenon is relevant as it suggests that youth share similar structural living condition and political macro-contexts in which they act and live. See Cavatorta, Francesco. "The convergence of governance: upgrading authoritarianism in the Arab world and downgrading democracy elsewhere?." Middle East Critique 19.3 (2010): 217-232; and Teti, Andrea, and Andrea Mura. "Convergent (il) liberalism in the Mediterranean? Some notes on Egyptian (post-) authoritarianism and Italian (post-) democracy." European Urban and Regional Studies 20.1 (2013): 120-127.
} 
otherwise very different young people seem to emerge insofar the individuals (and young people in particular) are called to a continuous reflexive activity, in order to make sense of the complex world they inhabit, to create and confirm their self-identity and, most of all, to figure out their own biographical projects. Young people are compelled to take the entire responsibility of their choices, to make sense of their present (in relation to their past experience) and to project themselves towards the future, to figure out their possible life trajectories, in contexts where the institutional markers of the transition to adult life are blurred, and where the very possibility to make long-term projects is weak. Both in Arab Mediterranean and Western context, the biographical representations of young men and women no longer adhere to linear models of transition, and can less and less be inspired by narratives rooted in tradition, or nurtured by the intergenerational transmission of values and imaginaries. Young people develop their copying strategies in their everyday lives and construct their own biographical projects drawing on the cultural resources available to them ${ }^{32}$, striving for reconstruct a possibility of control of their own social world. This can be seen as a crucial common trait under the biographies of young people from Arab Mediterranean countries and EU countries, that seems to short the distance between the experiences and lives deployed in such different contexts. In this frame, our aim in this WP is to explore whether and how these common trends are evident in the contexts under study and constitute a common ground for the youth subjects involved in the research. Can we envisage some shared biographical narratives that overcome the geographical boundaries?

In order to explore these main research questions, we suggest some key dimensions that should guide the analysis within the thematic Working Package 4. They can be detailed as follows:

\section{Changing values in young generations}

a) What are the changes taking place in today's Arab Mediterranean countries regarding social values and norms of young men and women in relation to family, gender relations, politics, participation, work and consume, and religion, among other issues?

b) How does youth agency contribute to making these changes visible? In which environment and 'social contexts' (school, family...) are these changes visible?

\section{Changes in the socio-cultural construction of youth and the emergence of autonomous youth cultures}

a) What are the main elements that describe the cultural construction of youth in the different contexts under study, and how are these elements changing?

\footnotetext{
${ }^{32}$ Meanings, imaginaries, models and desires, that seem to be increasingly shared at the global level - although the access to these cultural resources and the ability to make good use of them still depend upon the individual's structural position and the social, cultural and economic inequalities that exist within youth population in each local/regional/national context.
} 
b) In European and Western contexts, youth increasingly appears as a condition rather than a stage of transition, due to the processes of youth prolongation and fragmentation ("yo-yoization"). To what extent can this kind of construction be envisaged in the Arab Mediterranean countries?

c) Do we assist to the emergence of specific youth cultures in the contexts under study? For instance, we could ask whether urban young people are more likely to develop their own subcultures and differential identities, and to give rise to some form of cultural innovation, compared with young people in rural environments. We could explore the cultural practices of other specific youth sectors: the politically engaged youth; highly-educated young people or, on the contrary, marginal youth from poor neighbourhoods (since they lack the economic resources to complete the transition to adulthood and tend to stay longer in a liminal position); young women (since, in hypothesis, they inhabit a space of contradictions between the public and private spheres, and directly experience the rapid change in cultural values regarding the social position of women); young men and women who share a cosmopolitan or transnational view (e.g., because of mobility or contact with young migrants, or because of their intensive use of ICT and the consumption of global cultural goods), and so on.

\section{Youth cultures and difference}

a) How do youth cultural expressions and practices in the contexts under study vary in light of the differences that exist within the youth population? How do they differentiate following the different social locations of young people and also along the lines of gender, class, urban/rural origin, place of residence, ethnic and religious belonging, sexual orientation, ability, and so on?

b) Can we identify some prominent dimensions that seem to have a key role in the formation of specific youth subjectivities?

\section{Gender and youth cultures}

a) How does gender influence the formation process of new youth subjectivities and youth cultures in the contexts under study? (Intersects with WP5)

b) What are the specific social contradictions experienced by young women in Arab Mediterranean countries, who subsequently construct differential identities and subcultures?

c) In the case of some countries under investigation, we had a bold 'state feminism' under previous administrations. Do you see any difference in the conceptualisation and practice of feminism, after the Arab Uprisings?

5. Understanding youth cultures: advancing comprehensive interpretations of youth cultural practices in Arab Mediterranean countries. 
a) What are the dynamics underlying the emergence of specific youth cultures in the contexts under study? How can we interpret the youth cultural practices described in the fieldwork?

b) What are the relevant connections between the cultural and the structural aspects of youth condition in Arab Mediterranean countries? What is the impact of the structural changes, the transformation of the paths and pace of the transition to adulthood, on the emergence of new cultural trends among young generations? (e.g. exploring the impact of the prolongation of youth, youth unemployment, the growth of education rates among young men and women, etc)

c) Which connections can be traced between the transformations in values and cultural practices in young generations of Arab Mediterranean countries and the broader processes of social, political and economic change in these contexts? (e.g., explore the linkage with processes of individualisation; the expansion of education and high education; new cultural trends and changes in values among the whole population; processes of cultural globalisation and the emergence of a transnational sphere; financial and economic crisis, etc)

\section{Main trends and characters of youth cultures in Arab Mediterranean countries}

What are the main elements, contents and trends which characterise the youth cultural practices and subjectivities emerged from the fieldwork? In particular, the analysis should focus on the topics pointed out in the review of the contemporary literature and scholarship on youth culture, such as:

a) Consumption, use and meanings of leisure time, cultural consumption and the elaboration of life styles

b) The use and meanings of ICT and new digital media. How can the young generation of these countries drive new cultural trends via new communication channels? Which impacts have such new cultural trends on social media?

c) Political participation and civic engagement. To what extent does the emergence of new cultural trends among young generations connect with and foster civic and political engagements? What kind of cultural practices and subjectivities emerge in the mobilisation processes and the social movements that most involve young people in Arab Mediterranean countries? What is the importance of certain contemporary Muslim practices, or new values and perceptions towards religion, in the constitution of a special grammar in the use of public space $s$ and civic engagements? What is the importance of the alter-global vision for the engaged youth? What is the role of young women in the social movements and the forms of political engagement of the region?

d) The use and meanings of space and time. How do young people appropriate and use urban spaces as places to express new practices? What kinds of orientations do different young people express in relation to the past, the present and the future? How do young men and women perceive the future and how do they give expression to this perception in their everyday life, biographical projects and in their political/civic engagement? 
e) Identity and belonging. How do young people elaborate and give expression to their subjectivities and identities, through new cultural practices? How do they articulate their connection to the local and the global dimensions? Do they express their sense of belonging mostly with reference to a level or scale (e.g. the local, the city, the state, the Arab world..) or do they mix and articulate multiple belongings? To what extent and in which terms do they build new cosmopolitan identities?

\section{The "Arab youth": a new generation?}

a) To what extent and in what terms can we speak of the emergence of a new youth generation in Arab Mediterranean countries? Could we speak in proper terms of the "Arab youth" as a new generational actor in the social, cultural and political scenario of these countries?

b) Which are the main elements that unify this generation, and around which the creation of a generational bond can be envisaged? Which elements unify (and which elements divide and differentiate) the cultural and identity locations of young people in Arab Mediterranean countries today? For instance: the protests and the experience of the Arab Spring; or the experience of social exclusion, etc.

c) Is the involvement in social, cultural and political movements and grassroots mobilisation an element that fosters and creates the conditions for the emergence of a generational bond and of generational units among the Arab youths?

\section{The relationship between generations}

a) How is the relationship between young and adult generations in the contexts under study constructed? Additionally, how are the intergenerational relationships changing in the contemporary scenario of socio-economic crisis?

b) Do new forms of conflict between generations emerge? If they do emerge, what are the main cleavages that structure this conflict? If they do not, how can we interpret the tenure of intergenerational bonds, despite of the huge differences in social, economic and cultural resources available for young and adult generations?

c) In the European context it is widely recognised that a new social contract between generations is needed, especially in relation to the economic and professional opportunities. How about the Arab Mediterranean countries? Is there a similar concern and public debate around this issue? Do people (and young people) express a similar perception of this issue?

9. Youth cultures, youth empowerment and the broader impact on social, political and cultural change in the region

a) Is the creation of new lifestyles and the emergence of new youth cultures an indicator of socio-political transitions? 
b) How can young women and young men be empowered to take part in the new cultural drives in the region? How does this empowerment specifically differ in relation to gender?

c) What kind of impacts result from new cultural trends in empowering youth in everyday life, both in microeconomic entrepreneurship and in fuelling social movements in such countries?

\section{Arab youths and global youths}

a) Which elements unify, and which elements divide and differentiate, the cultural and identity locations of young people in Arab Mediterranean countries and in European countries? Can we identify some commonalities that seem to reduce differences among young people from different contexts and in particular, from Arab Mediterranean countries and European countries? To what extent can we identify some common, transversal elements that seem to mark the contemporary youth condition in the global context?

b) Can we envisage some commonalities between the cultural, economic, political and biographical transformations that young people in Arab Mediterranean countries are facing, and the experiences of young people in post-1989 Eastern Europe? (Intersects with WP 8).

c) How would we assess (if any) the cultural influence that migration processes carry? The Arab Mediterranean countries are indeed in a crucial position within multiple migration trajectories as they both send migrants (to Europe, for instance) but also receive many migrants from the sub-Saharan Africa, in the case of Southern Med countries, and from Central Asia in the case of Eastern Med countries, notably Turkey in particular. (Intersect with WP6).

\section{Youth cultures and policies in Arab Mediterranean countries (intersects with WP7)}

a) What about the interaction between governmental policies and the definition of youth? Do you identify any specific policy (advanced by local authorities or national governments) that relates directly to the socio-cultural construction of youth?

b) How do national governments react to youth's changing values in terms of policies? Are some policies changing to specifically "respond" to specific changes of values?

c) In terms of policy-making process, are youth organisations involved?

d) Which kind of cleavages such an involvement in policy-making does create between youth organisations and policy-makers? Or is a relationship of collaboration (co-option) dominant?

e) Which kind of cleavages the involvement in policy-making does create among youth organisations? 


\section{ANNEX I}

\section{References on Youth Studies in Morocco}

Fadma Aït Mous, Driss Ksikes,

Institut des Hautes Etudes de Management, Morocco

- Adam (André), 1972, Casablanca : essai sur la transformation de la société marocaine au contact de l'Occident, Paris : CNRS éditions,

- Adam André, 1963, Une enquête auprès de la jeunesse musulmane du Maroc, Aix-enProvence, La Pensée universitaire

- Affaya N. et Guerraoui D. (2006), Le Maroc des jeunes, publications de l'Association de Recherche en communication Interculturelle.

- Assia Belhabib (dir.), Quand le printemps est arabe, Editions La croisée des chemins, Casablanca, 2014.

- Bennani-Chraïbi (Mounia), 1994, Soumis et rebelles : les jeunes au Maroc, Paris, CNRS éditions

- Bennani-Chraïbi (Mounia), 1998, «Les Jeunes comme acteurs sociaux : le cas du Maroc » In Kilani (Mondher) (sous la dir.), Islam et changement social, Lausanne, Editions Payot Lausanne

- Bennani-Chraibi M. (1998), Constructing Youth in the Mediterranean Societies, Archives de la Commission Européenne.

- Bichara Khader, Le monde arabe expliqué à l'Europe, histoire, imaginaire, culture, politique, économie, géopolitique, Co-ed. Academia - Bruylant,2009.

- Bourqia (Rahma), 2006, Les valeurs : changements et perspectives. Rapport en ligne: http://www.rdh50.ma/fr/pdf/contributions/GT2-3.pdf

- Bourqia (Rahma), El Ayadi (Mohammed), El Harras (Mokhtar), Rachik (Hassan), 2000, Les Jeunes et les valeurs religieuses, Casablanca, Eddif-CODESRIA 
- Bourqia (Rahma), El Harras (Mokhtar), Bensaïd (Driss), 1995, Jeunesse estudiantine marocaine : valeurs et stratégies, Rabat, Faculté des lettres et des sciences humaines

- Dominique Caubet et Catherine Miller, Parlers jeunes, ici et là-bas :pratiques et représentations, Ed. L’Harmattan, 2011.

- El Aoufi N. \& Bensaïd M. (2005), Chômage et employabilité des jeunes au Maroc, Cahiers de lastratégie de l'emploi, 2005/06.

- El Ayadi Mohammed, Rachik Hassan, TozyMohamed, L'Islam au quotidien. Enquête sur les valeurs et les pratiques religieuses au Maroc, Casablanca, Prologues, coll : Religion et société, 2007, 272 p.

URL :http://www.fes.org.ma/common/pdf/publications_pdf/islam_qut_gr/islam_qut_gr.pdf

- El Khyari Rkia, 2004, Jeunesse marocaine et valeurs démocratiques, Rabat, Fondation Friedrich Ebert.

- Hamimaz Mériem, 2003, Elections et communication politique dans le Maroc rural : une investigation dans une région du Moyen Atlas, Ribat El Kheir, Casablanca : Impr. Najah el jadida,

- Mohamed Jeghllaly, 2005, Représentations sociales du «politique » chez les jeunes : le cas des communes rurales Bni Ydder, Tanakob et Tassifte, mémoire DESA 2005.

- Pascon Paul, Bentahar Mekki, 1978, «Ce que disent 296 jeunes ruraux » In Etudes sociologiques sur le Maroc, (Recueil d'articles conçu et préparé par Abdelkébir Khatibi), Tanger : Editions marocaines et internationales, p. 145-287.

- Rachik Hassan (rap.), 2005, «Jeunesse et changement social », in 50 ans de Développement Humain et Perspective 2025.

- Rachik, Hassan Jeunesse et groupes d'âge en milieu rural, Collectif, Jeunesse et société dans les pays du Maghreb, 1991, Faculté des Sciences de l'éducation, Rabat.

- Rahma Bourqia, "Valeurs et changement socialau Maroc » in Quaderns de la Medierrania 13, URL:http://www.iemed.org/publicacions/quaderns/13/qm13_pdf/14.pdf 
Yves Gonzalez-Quijano, Tourya Guaaybess, «Les Arabes parlent aux arabes : la révolution de l'information dans le monde arabe », Actes Sud, 2009.

- Revue Economia, dossier « Avoir 20 ans en $2011 », n^{\circ}$ 12, juillet - octobre 2011.

- Sylvie FLORIS, Etudes sur les politiques Jeunesse des pays partenaires Méditerranéens, Maroc, Programme EuroMed Jeunesse III, 2010. Url :

URL: http://ourahou.e-monsite.com/medias/files/valeura474pages.pdf

Youth and Mediterranean Challenges, Quaderns de la Mediterrania 11, IEMed.

http://www.euromedyouth.net/IMG/pdf/06-EuroMedJeunesseEtude_MAROC_FR_090708.pdf

Enquêtes sur les jeunes :

- Banque Africaine de Développement, 2011, Comment lutter contre le chômage des jeunes au Maghreb.

- Banque Africaine de Développement, 2012, L’inégalité et les révolutions du printemps arabe en Afrique du Nord et au Moyen Orient

- Banque mondiale, 2012, Promouvoir l'égalité et la participation des jeunes, Moyen-Orient et Afrique du Nord, rapport du département du développement durable.

- Centre d'Etudes et de Recherches Démographiques (CERED), 2004, Rapport de la politique de population. La jeunesse marocaine: attitudes, comportements et besoins, publié sur

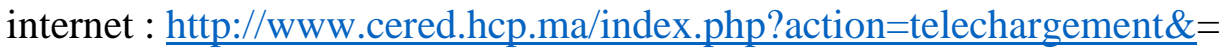

- CERED, 2000. Les indicateurs de suivi et d'évaluation de la politique de population au Maroc. Publié sur URL:

http://www.cered.hcp.ma/index.php?action=article\&id_article=173304 
- CERED, 2004, Adolescence en question: analyse des résultats de l'enquête sur les adolescents dans les milieux semi-urbain et rural de Marrakech, publié sur internet: http://www.cered.hcp.ma/index.php?action=telechargement $\&=$

- CERED, 2004, Adolescence en question: analyse des résultats de l'enquête sur les adolescents dans les milieux semi-urbain et rural de Marrakech, en ligne : $\underline{\text { http://www.cered.hcp.ma/index.php?action=telechargement } \&=}$

- CERED, 2004, Rapport de la politique de population. La jeunesse marocaine: attitudes, comportements et besoins, en ligne:

http://www.cered.hcp.ma/index.php?action=telechargement\&=

- Conseil économique et social et Conseil supérieur de 1'Enseignement, 2011, Employabilité des jeunes : les voies et les moyens. Agir sur le chômage et s'engager pour l'emploi qualifié. Sous la direction de Noureddine EL AOUFI et Said HANCHANE.

- Conseil National de la Jeunesse et de l'Avenir, 1991, une enquête nationale sur le chômage des jeunes diplômés.

- Conseil National de la Jeunesse et de l'Avenir, 1994, Enquête nationale auprès des jeunes 1993. Analyse des résultats (4 vol), Publications du CNJA.

- Conseil National de la Jeunesse et de l'Avenir, 1995, Les jeunes et l'entreprise : nouveaux enjeux. Programme d'action.

- Conseil National de la Jeunesse et de l'Avenir, 1998, Enquête nationale : jeunes et administration 1998, présentation sommaire des résultats, Rabat : Publications du CNJA.

- Direction de la jeunesse et de 1'Enfance, 2001, Consultation nationale des jeunes : Enquête auprès de 18109 jeunes, Rabat.

- FONDAPOL (2011), 2011 World Youths, www.fondapol.org

- Haut Commissariat au Plan, 2004 «Rapport national sur la politique de la population 2004 : La Jeunesse Marocaine, situation actuelle et perspectives » 
- Le Journal l'Economiste, Février 2006, Les documents de l'économiste, numéro spécial à propos de l'enquête Sunergia/Economiste sur les jeunes marocains, Hors série, Casablanca.

- Ministère de la Jeunesse et Sports, Direction de la jeunesse et de l'Enfance, 2001, Consultation nationale des jeunes : Enquête auprès de 18109 jeunes, Rabat.

$$
\begin{aligned}
& \text { مراجع حول الثبيبة المغربية: } \\
& \text { ـ ابن طاهر (المكي)، باسكون (بول) ، 1972، "الثبيبة القروية في المغرب" ؛ عربه محمد المعروفي ؛ هيأته زبيدة } \\
& \text { بورحيل، في البحث العلمي، ع. 19، ص. 111-231 } \\
& \text { ـ الثباب و المجتمع في البلدان المغاربية [أعمال الندوة المنعقدة] من } 11 \text { إلى } 13 \text { دجنبر } 1991 \text { الني نظمتها كلية علوم } \\
& \text { التربية ـ ـ الرباط : كلية علوم التربية, [-199؟] } \\
& \text { - بورقية (رحمة) ؛ [حاور ها لحسن لعسبي]،1998، "السوسيولوجياوقيم الثباب : إنثكالية المجتمع المدني "، في مجلة } \\
& \text { الثعلة . - ع. 2، ص. 26-22 } \\
& \text { - جمعية الثعلة، 2003، الثباب و التربية على الديمقر اطية و حقوق الإنسان و المواطنة: بحث إستطلاعيـ المو اقف و } \\
& \text { التمثلات، الدار البيضاء، منشور ات الثعلة. } \\
& \text { ـ منصف (يوسف)،2007، التمثلاث الدينية عند الثباب المغربي: در اسة حالة طلبة جامعة الحسن الثاني/ البيضاء، رسالة } \\
& \text { دبلوم السلك الثالث،شعبة القانون العام بجامعة الحسن الثاني/ البيضاء. } \\
& \text { ـ عليوة (خالد) ، 1986،"الثباب و التغيير الاجتماعي "، في المشروع : من أجل نوطيد الفكر الاشتر اكي، - ع. 6، ص. } \\
& \text { - بورقية (رحمة) ؛ [حاور هالحسن لعسبي]،1998، "السوسيولوجيا وقيم الثباب : إنكالية|لمجتمع المدني "،في مجلة } \\
& \text { الثعلة . - ع. 2،ص. 22-22 } \\
& \text { - جمعيةالثعلة، 2003،الثباب و التربية على الديمقر اطية وحقوق الإنسان و المو اطنة: بحث إستطلاعيـ المو اقف } \\
& \text { و التمثلات،الدار البيضاء،منشور ات الشعلة. }
\end{aligned}
$$


Youth Cultures: Values, Representations and Social Conditions 


\section{Her \\ Lam \\ 5ahwa}

Towards a New Social Contract

www.sahwa.eu

The SAHWA Project ("Researching Arab Mediterranean Youth: Towards a New Social Contract") is a FP-7 interdisciplinary cooperative research project led by the Barcelona Centre for International Affairs (CIDOB) and funded by the European Commission. It brings together fifteen partners from Europe and Southern and Eastern Mediterranean countries to research youth prospects and perspectives in a context of multiple social, economic and political transitions in five Arab countries (Morocco, Algeria, Tunisia, Egypt and Lebanon). The project expands over 20142016 and has a total budget of $€ 3.1$ million. The thematic axis around which the project will revolve are education, employment and social inclusion, political mobilization and participation, culture and values, international migration and mobility, gender, comparative experiences in other transition contexts and public policies and international cooperation.
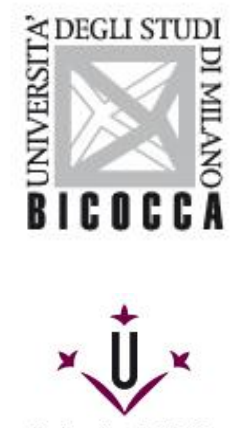

Universitat de Lleida

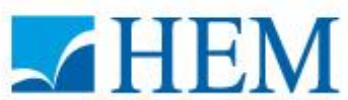

La performance réfléchie

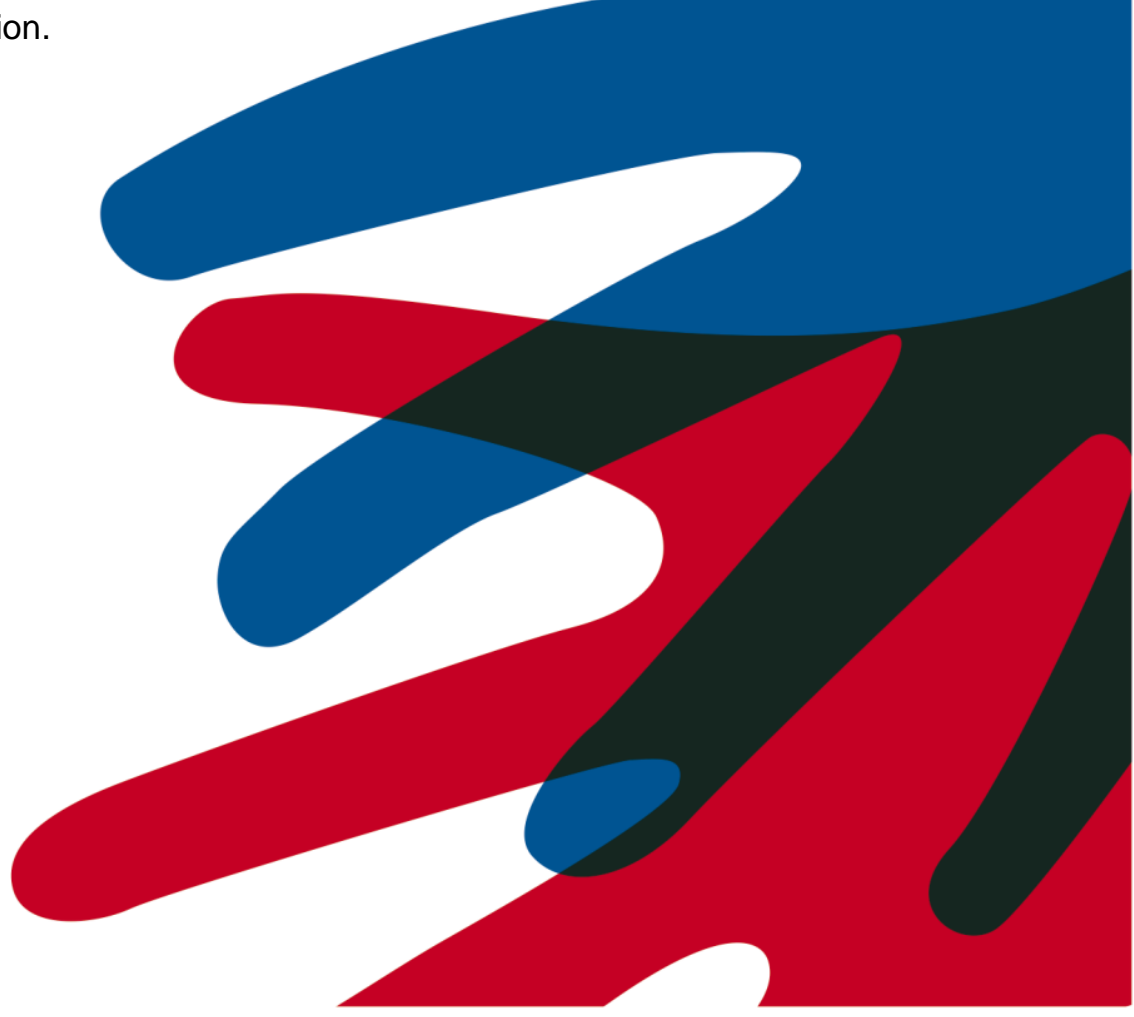

